УДК $577+579+550.72$

PACS 87.23.-n

\title{
БАКТЕРИАЛЬНЫЕ СООБЩЕСТВА \\ МЕРЗЛЫХ ЧЕТВЕРТИЧНЫХ ПОРОД МОРСКОГО ГЕНЕЗИСА НА ПОБЕРЕЖЬЕ О. ЗАПАДНЫЙ ШПИЦБЕРГЕН
}

\author{
(C) 2021 г. Е.С. Караевская ${ }^{1,2}$, Н.Э. Демидов ${ }^{1}$, В.С. Казанцев ${ }^{3}$, И.М. Елизаров ${ }^{4}$, А.Г. Калошин ${ }^{5}$, \\ А.Л. Петров ${ }^{5}$, Д.С. Карлов ${ }^{6}$, Л. Ширрмайстер ${ }^{7}$, А.А. Белов ${ }^{8}$, С. Веттерих ${ }^{7}$
}

${ }^{1}$ Государственный научный центр Российской Федерации «Арктический и антарктический научно-исследовательский институт», г. Санкт-Петербург, Россия

${ }^{2}$ Институт общей генетики имени Н.И. Вавилова РАН, г. Москва, Россия

${ }^{3}$ Институт физики атмосферы имени А.М. Обухова РАН, г. Москва, Россия

${ }^{4}$ Федеральный исследовательский центр «Фундаментальные основы биотехнологии» РАН,

Институт микробиологии имени С.Н. Виноградского РАН, г. Москва, Россия

${ }_{5}^{5}$ Научно-аналитический центр, Апрелевское отделение Всероссийского научно-исследовательского геологического нефтяного института, Московская обл., г. Апрелевка, Россия

${ }^{6}$ Всероссийский научно-исследовательский институт сельскохозяйственной микробиологии, г. Санкт-Петербург; г. Пушкин, Россия

${ }^{7}$ Институт Альфреда Вегенера Центра полярных и морских исследований имени Гельмгольца, отдел исследований вечной мерзлоты, г. Потсдам, Германия

${ }^{8}$ Московский государственный университет имени М.В. Ломоносова, факультет почвоведения, г. Москва, Россия

*e-mail: katya_k_s@mail.ru

Поступила в редакцию 30.09.2020 г.; после доработки 12.04.2021 г.

Принята к публикации 16.04.2021 г.

\begin{abstract}
Аннотация. Изучено бактериальное разнообразие образцов вечной мерзлоты, полученных при бурении мерзлых четвертичных отложений морского генезиса на восточном побережье зал. Гренфьорд о. Западный Шпицберген. Исследование основано на анализе V4 региона гена $16 \mathrm{~S}$ pРНК, проведенного с помощью секвенирования нового поколения, а также с применением классических микробиологических методов (прямой люминесцентной микроскопии, аэробного культивирования). Общее количество клеток в образцах вечной мерзлоты варьировало от $6.73 \pm 0.73 \cdot 10^{6}$ до $3.37 \pm 0.19 \cdot 10^{7}$ ед. в 1 г мерзлоты. Количество культивируемых аэробных бактерий в образцах мерзлоты на средах $1 / 5$ TSA и $\mathrm{R}_{2} \mathrm{~A}$ составило от 0 до $6.20 \pm 0.45 \cdot 10^{4}$ KОЕ в 1 г мерзлоты. Изоляты аэробных бактерий были идентифицированы с помощью анализа гена $16 \mathrm{~S}$ рРНК как представители родов Arthrobacter, Pseudarthrobacter, Psychrobacter и Rhodoferax. Доминирующими филумами домена Bacteria были Actinobacteria, Proteobacteria, Chloroflexi, Nitrospirae и Firmicutes. В результате филогенетического анализа доминирующих оперативных таксономических единиц были обнаружены представители метанокисляющих и сульфатредуцирующих бактерий, а также гетеротрофных бактерий, участвующих в преобразовании органического вещества.
\end{abstract}

Keywords: о. Западный Шпицберген, вечная мерзлота, морские осадки, культивируемые аэробные бактерии, V4 регион гена 16S рРНК, домен Васteria, метан.

DOI: https://doi.org/10.21455/GPB2021.2-5

Цитирование: Караевская Е.С., Демидов Н.Э., Казанцев В.С., Елизаров И.М., Калошин А.Г., Петров А.Л., Карлов Д.С., Ширрмайстер Л., Белов А.А., Веттерих С. Бактериальные сообщества мерзлых четвертичных пород морского генезиса на побережье о. Западный Шпицберген // Геофизические процессы и биосфера. 2021. Т. 20, № 2. С. 75-98. https://doi.org/10.21455/GPB2021.2-5

\section{ВВЕДЕНИЕ}

Архипелаг Шпицберген - уникальный регион Арктики, где фиксируются быстрые процессы, связанные с потеплением климата. Так, согласно метеорологическим данным, в поселении Лонгйир среднегодовая температура воздуха в течение XX в. повысилась примерно с -9 до $-4{ }^{\circ} \mathrm{C}$ [Humlum et al., 2003]. Площадь ледников в окрестностях Лонгйира и Баренцбурга уменьшилась примерно в 2 раза с 1936 по 2017 г. [Чернов,
Муравьев, 2018]. Вечная мерзлота Шпицбергена наиболее теплая в высоких широтах из-за отепляющего влияния течений и воздушных масс, переносимых из Атлантики Западным Шпицбергенским течением. В 2016 г. в рамках создания криосферного полигона Российского научного центра в районе рудника Баренцбург на восточном берегу зал. Гренфьорд были пробурены скважины для изучения структурных особенностей вечной мерзлоты и мониторинга 
eе температуры [Демидов и др., 2016б; Demidov et $a l ., 2019]$. Скважинами вскрыты прибрежно-морские мерзлые отложения, замерзшие в позднем плейстоцене и голоцене после выхода из-под уровня моря.

Настоящее исследование - продолжение работ по всестороннему изучению вечной мерзлоты в районе рудника Баренцбург в ключе микробиологической характеристики мерзлоты, что дает возможность начать изучение происходящих в мерзлоте биогеохимических процессов. Сравнительное микробиологическое исследование арктических систем «морская вода - морские отложения» и «наземная мерзлота подводная мерзлота» показывает различия между доминирующими группами бактерий. Так, для домена Bacteria, исследованного на шельфе моря Бофорта (Аляска), наблюдалась смена доминирующих групп с Alpha-, Gammaproteobateria и Bacteroides в морской воде на Deltaproteobacteria, Firmicutes, Chloroflexi, Actinobacteria и Cyanobacteria в нижележащих незамерзших морских отложениях. Сравнение наземной и подводной вечной мерзлоты возрастом около 2500 лет, изученной в районе м. Мамонтов Клык (западная часть моря Лаптевых), показало увеличение доли Deltaproteobacteria, Actinobacteria, Gemmatimonadetes, а также группы KD4-96 (Chloroflexi) и уменьшение доли филума Firmicutes [Mitzscherling et al., 2019]. А отложения морского шельфа в районе моря Д’Юрвиль (Восточная Антарктида), согласно DGGE-анализу генов 16S pРНК, содержали в основном классы Deltaproteobacteria, предполагаемые сульфидокисляющие группы Gammaproteobacteria, а также классы Flavobacteria и Planctomycetales [Bowman et al., 2003].

Что касается арх. Шпицберген, то на настоящее время работ, описывающих состав бактериальных сообществ морских отложений и вечной мерзлоты, немного. Так, в работе [Srinivas et al., 2009] описаны выделенные из современных морских отложений зал. Конгсфьорд чистые культуры, относящиеся к филумам Actinobacteria, Bacteroidetes и Proteobacteria (Alpha- и Gamma-). В работе [Teske et al., 2011] методом профилирования гена $16 \mathrm{~S}$ рРНК установлено увеличение доли Deltaproteobacteria, Chloroflexi и Planctomycetes при переходе от морской воды к морским отложениям зал. Смеринбург-фьорд. Обнаружено присутствие филотипов $16 \mathrm{~S}$ рРНК, образующих эндоспоры термофильных представителей филума Firmicutes, в морских незамерзших отложениях крупных фьордов арх. Шпицберген [Müller et al., 2014]. Изучение поверхностных и приповерхностных голоценовых отложений в долине Адвентдален до глубины 2 м выявило смену доминирующих групп домена Bacteria от Proteobacteria (Alpha-, Beta-, Gamma-), Acidobacteria, Veruccomicrobia и Actinobacteria (порядок Thermoleophilia) в сезонно-талом слое к Actinobacteria (семейство Intrasporangiaceae) в слое вечной мерзлоты [Müller et al., 2018]. Однако исследования более древних мерзлых пород на арх. Шпицберген с использованием метода секвенирования нового поколения практически не проводились.

Целью нашей работы было охарактеризовать многолетнемерзлые прибрежные морские отложения, охватывающие весь высотный и возрастной диапазон лестницы морских террас в районе Баренцбурга, с помощью методов анализа V4 региона гена 16S pPHK бактерий, а также культивирования аэробных бактерий при $10{ }^{\circ} \mathrm{C}$ для получения представления о структуре бактериальных сообществ и микробиологических процессах, происходивших в морских осадках до их замерзания на длительное время. Это первая часть исследования, посвященная домену Bacteria.

\section{ОБЪЕКТЫ ИССЛЕДОВАНИЯ}

В исследовании использовались керны вечной мерзлоты из скв. 1 (78.02289 2 м над ур. моря), пробуренной в устье р. Грен, скв. 2 (78.09504ㅇ с.ш., $14.24096^{\circ}$ в.д., 75.5 м над ур. моря)

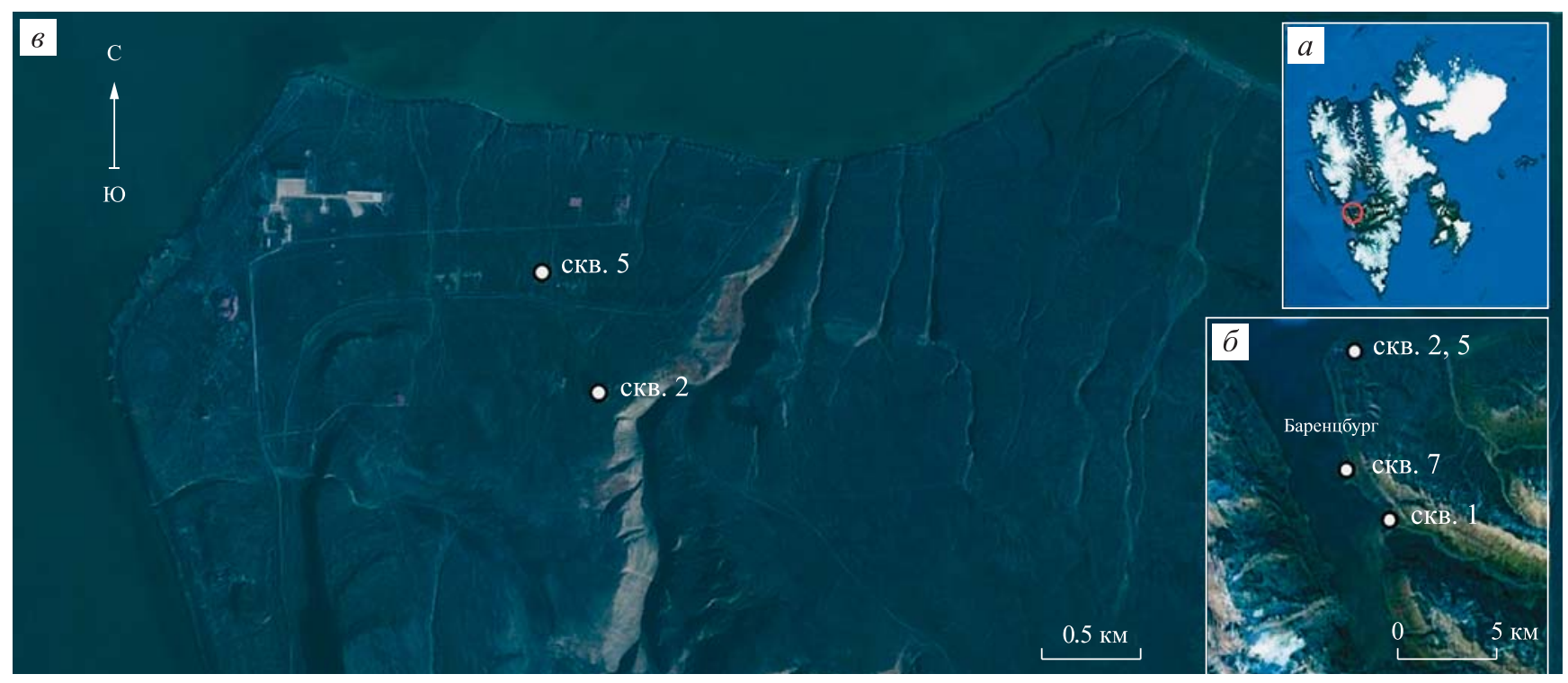

Рис. 1. Местоположение изучаемой территории на арх. Шпицберген и на криосферном полигоне в районе Баренцбурга (a) и расположение скважин 1, 2, 5 и 7 (б) и скважин 2 и 5 (в) (спутниковые снимки взяты с сайтов https://google.ru/maps и https://toposvalbard.npolar.no) 
Бактериальные сообщества мерзлых четвертичных пород морского генезиса...
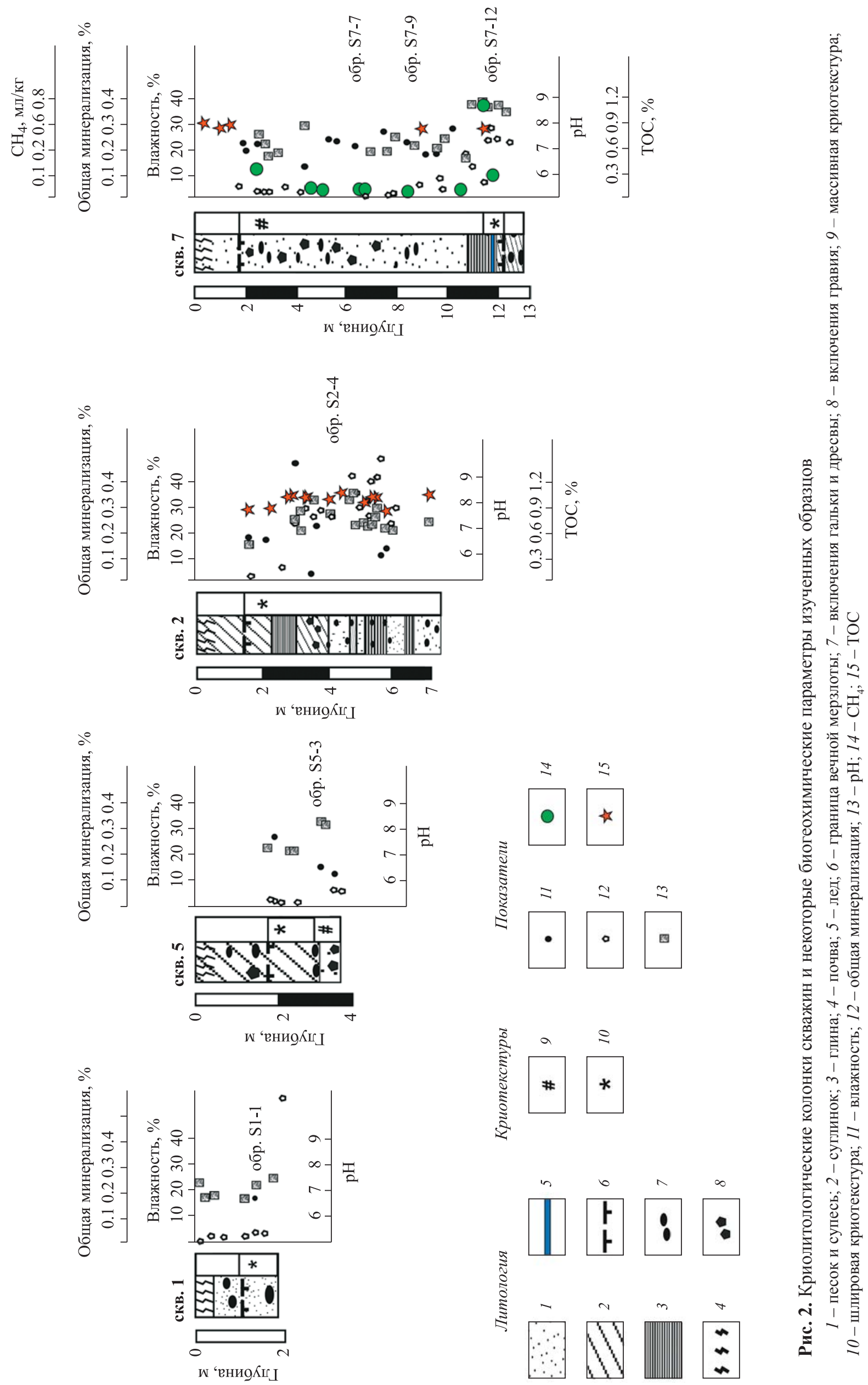
и скв. 5 (78.09856 ${ }^{\circ}$ с.ш., $14.23299^{\circ}$ в.д., 43 м над ур. моря), пробуренных на южном берегу зал. Исфьорд, а также скв. 7 (78.04703 с.ш., $14.21962^{\circ}$ в.д., 8 м над ур. моря), пробуренной на м. Финнесет (рис. 1).

Литологический состав колонок показан на рис. 2. Отложения представлены песками, супесями, суглинками и глинами прибрежно-морского генезиса, которые накапливались на дне моря в позднем плейстоцене и голоцене, а затем, при резком падении относительного уровня моря, выходили на поверхность, промерзали и покрывались маломощным покровом континентальных отложений различного генезиса [Svendsen, Mangerud, 1997; Forman et al., 2004].

Среднегодовая температура в скв. 2 на глубине 5.5 м за период 25.09.2018 г. - 25.08.2019 г. составила $-2.17^{\circ} \mathrm{C}$, а однократное измерение (12.09.2016 г.) температуры в скв. 7 на глубине 12.5 м показало температуру $-0.87{ }^{\circ} \mathrm{C}$ [Демидов и др., 2020]. Несмотря на то что в современную эпоху эти отложения являются мерзлыми, породы на глубине менее 3 м могли оттаять во время голоценового потепления, когда глубина сезонного протаивания превышала современную. В случае скв. 1 кратковременное повышение уровня моря могло вызвать временное оттаивание отложений, которые в настоящее время являются мерзлотой [Salvigsen, Høgvard, 2005; Соловьева и др., 2018].

Образцы, взятые для секвенирования нового поколения, были обозначены согласно номерам скважин и глубинам отбора (м) - S1-1, S2-4, S5-3, S7-7, S7-9 и $\mathrm{S} 7-12$. Образец, взятый с глубины 5 см над скв. 1, представлял собой окисленный глеевый горизонт $\mathrm{G}_{\text {ох }}$ глеевой почвы [Алексеев, Абакумов, 2016].

\section{МЕТОДЫ ИССЛЕДОВАНИЯ}

Отбор проб. Бурение проводилось в августесентябре 2016 г. буровой установкой УКБ 12/25 (изготовитель - завод бурового оборудования им. В.В. Воровского, г. Екатеринбург, Россия) без промывки и без добавления химических реагентов. Использовались тонкостенные колонковые трубы с внешним диаметром от 76 до 112 мм. После очистки поверхности мерзлых сегментов керна стерильным скальпелем образцы помещали в стерильные пакеты (Whirl-Pak®, Nasko, CШA) и хранили при температуpe $-4 \div-10{ }^{\circ} \mathrm{C}$. 28 октября 2016 г. они были доставлены в лабораторию ЛИКОС (ГНЦ РФ «Арктический и антарктический научно-исследовательский институт»), где хранились в морозильной камере при $-18^{\circ} \mathrm{C}$. Анализ образцов проводился в период с октября 2016 г. по февраль 2020 г.

Анализ содержсания метана в образцах. Для анализа газов была выбрана скв. 7 как наиболее глубокая (12 м) и обильная по образцам. Газовую фазу образцов мерзлоты отбирали с помощью дегазации методом headspace в шприцах объемом 150 мл [Alperin et al., 1985]. Специальный анализ концентраций метана в пробах проводили в трех повторностях на газовом хроматографе «Кристалл 5000.2» (ЗАО «Хроматэк», г. ЙошкарОла, Россия) с пламенно-ионизационным детектором. Технические параметры хроматографа и условия проведения анализа следующие: длина хроматографической колонки -3 м, диаметр - 2 мм, температура $-60{ }^{\circ} \mathrm{C}$, адсорбент - Хайесеп-Н 80/100, температура пламенноионизационного детектора $-150{ }^{\circ} \mathrm{C}$. Объем пробоотборника -0.25 мл, объем вводимой пробы газа -3-8 мл. В качестве газа-носителя использовали азот (чистота 99.999\%) со скоростью потока 30 мл/мин. Расход водорода - 20 мл/мин, расход воздуха - 400 мл/мин. Для калибровки хроматографа использовали газовые смеси (ООО «Мониторинг», г. Санкт-Петербург, Россия) со следующими концентрациями метана: $0.49 \pm 0.07$, $5.3 \pm 0.5,10.3 \pm 0.6,100 \pm 5,1000 \pm 30$ ppm.

Изотопный состав метана и углекислого газа. $\delta^{13} \mathrm{C}$ метана и диоксида углерода от стандарта VPDB (Vienna Pee Dee Belemnite) [Miller, Wheeler, 2012] образца с глубины 2.3 м из скв. 7 экспериментально измеряли с помощью масс-спектрометра DeltaV Advantage в сочетании с газовым хроматографом Thermo Science Trace 1310 (компания Thermo Fisher Scientific, США) в лаборатории Научно-аналитического центра Апрелевского отделения Всероссийского научно-исследовательского геологического нефтяного института (Московская обл., г. Апрелевка, Россия).

Измерения общего органического углерода и радиоуллеродное датирование. Общее содержание органического углерода (TOC - total organic carbon) определяли в образцах из скважин 2 и 7 (всего 18 проб). Значения даны в процентах по массе (мас. \%). Анализы выполнены на элементном анализаторе (Elementar Vario MAXC; аналитическая точность \pm 0.1 мас. \%). Собранный вручную органический материал из двух образцов скв. 7 был подвергнут радиоуглеродному датированию с помощью ускорительной масс-спектрометрии (AMS) c использованием системы минидатирования углерода (MICADAS) в Институте Альфреда Вегенера Центра полярных и морских исследований имени Гельмгольца. Дополнительные сведения о лабораторных процедурах и предварительной обработке образцов приведены в [Opel et al., 2019; Mollenhauer et al., 2021]. Все радиоуглеродные даты были откалиброваны с использованием набора калибровочных данных IntCal13 [Reimer et al., 2013]. Возраст указан числом лет до настоящего времени (калибровочное число лет).

Прямой счет клеток. Кусочки образцов переносили в стерильные пробирки Falcon объемом 15 мл (Eppendorf, Германия), добавляли 3-5 мл буфера PBS, состоящего из 137 мм NaCl, 2.7 мм KCl, 15 мм $\mathrm{Na}_{2} \mathrm{HPO}_{4}$ и 1.7 мм $\mathrm{KH}_{2} \mathrm{PO}_{4}$ (рН 7.6 в воде), как описано в [Mitzscherling et al., 2017], после чего фиксировали конечный объем образца. Затем образцы встряхивали до образования однородной суспензии и обрабатывали ультразвуком низкой интенсивности в ультразвуковой ванне с частотой 35 кГц 30 с (завод «Сапфир», г. Москва, Россия) с мощностью 200 Вт. После этого пробирки помещали в штатив на 10 мин для отделения крупных частиц минеральной фазы. Затем 100 мкл жидкости из середины суспензии переносили в пробирку на 0.5 мл, смешивали со 100 мкл 0.01\%-ного акридинового оранжевого и инкубировали в течение 1 мин при комнатной температуре. Аликвоту 2 мкл окрашенной суспензии наносили на предметное стекло и покрывали покровным стеклом 18×18 мм. Флуоресцентную микроскопию выполняли с помощью эпифлуоресцентного микроскопа Axio Lab.A1 (фирма Zeiss) с использованием фильтра Fs.09 (ВР 450-490, 
FT 510, LP515) для акридинового оранжевого. Подсчет клеток проводили в трех повторностях в поле зрения $(d=200$ мкм) с просмотром 10 полей для каждой повторности. Концентрацию клеток в суспензии рассчитывали, умножая среднее количество клеток на поле на $1.032 \cdot 10^{7}$. Первоначальную концентрацию клеток в 1 г рассчитывали путем умножения количества клеток в суспензии на ее объем и деления результата на массу исходного образца мерзлоты.

Культивирование аэробньх бактерий. Для определения количества аэробных бактерий в стерильной зоне пламени горелки из центральной части керна отбирали кусочки образцов мерзлоты массой 0.4-2.7 г и помещали их в пластиковые пробирки с 4.9-7.4 мл автоклавированной дистиллированной воды. Затем содержимое пробирок суспензировали вручную в течение 10 мин до равномерного распределения частиц по объему. Суспензии (степень разведения 1:10 и 1:100) высевали на твердые питательные среды 1/5TSA (триптиказо-соевая среда, FlukaTripticSoyBroth №2, США) и $\mathrm{R}_{2} \mathrm{~A}$ (Difco $\left.{ }^{\mathrm{TM}}, \mathrm{CШA}\right)$, широко используемые для образцов мерзлоты [Vishnivetskaya et al., 2000; Gilichinsky et al., 2007; Steven et al., 2007], в двух повторностях и культивировали в течение 15 дней при средней температуре $10{ }^{\circ} \mathrm{C}$, комфортной для роста психотолерантной части сообщества. Расчет количества культивируемых клеток проводили по формуле

$$
N=(a \cdot P \cdot b) / m,
$$

где $a$ - количество колоний на чашке; $P$ - разведение; $b$ - количество капель в 1 мл; $m$ - масса образца.

Выделение ДНК, подготовка и секвенирование ампликоновых библиотек. ДНК из образцов выделяли с помощью набора Fast DNA Spin Kit for Soil согласно методике производителя (MP Biomedicals, CША). Концентрацию измеряли на флуориметре Qubit 2.0 с набором реагентов dsDNAH Sreagent KIT (Invitrogen ${ }^{\mathrm{TM}}$, США). Библиотеки ампликонов создавали в Институте микробиологии им. С.Н. Виноградского РАН (г. Москва, Россия) с помощью полимерной цепной реакции (метод ПЦР) с универсальными праймерами для области V4 в соответствии с ранее описанной методикой [Fadrosh et al., 2014]. Праймеры были выбраны для наиболее объективного соотношения доменов бактерий и архей: 515F (5'- GTGBCAGCMGCCGCGGTAA - 3') [Hugerth et al., 2014] и Pro-mod-805R (5'-GACTACNVGGGTMTCTAATCC-3') [Меркель u дp., 2019]. Секвенирование проводили на системе MiSeq (Illumina, США) в OОО «Биоспарк» (г. Москва; г. Троицк, Россия) с использованием реакции Miseq Reagent Micro KITv2, считывающей 150 нуклеотидов с каждого конца. Каждый образец был прочитан в двух повторностях, включая контрольные образцы реактивов и лабораторного воздуха, используемых для вычитания загрязняющих последовательностей из исследуемого образца. Всего было получено 164843 последовательности.

Биоинформатический и статистический анализ. Демультиплексирование, а также последующую обработку и анализ последовательностей проводили с использованием соответствующих алгоритмов в программе QIIME 2 ver 2019.1 [Bolyen et al., 2019]. Оперативные таксономические единицы (ОТЕ) идентифицировали с помощью программ SILVAngs 1.4 pipeline (https://ngs. arb-silva.de/silvangs/) и BLAST (http://blast.ncbi.nlm.nih. gov/Blast.cgi). Все индексы рассчитывались для ненормированных данных. Индекс покрытия ампликоновых библиотек рассчитывался по формуле

$$
C=1-n / N,
$$

где $n$ - количество ОТЕ, представленных одним ампликоном; $N$ - общее количество ампликонов [Good, 1953].

Индекс Чао1 [Chao, 1984] рассчитывался по формуле

$$
\text { Чao1 }=S_{o b s}+\left(a^{2} / 2 b\right),
$$

где $S_{o b s}$ - идентифицированное количество филотипов (ОТЕ); $a$ - количество филотипов (ОТЕ), представленных одним ампликоном; $b$ - количество филотипов, представленных двумя ампликонами.

Индекс Шэннона-Уивера [Мэгарран, 1992] вычислялся по формуле

$$
H^{\prime}=-\sum_{i} p_{i} \ln p_{i},
$$

где $p_{i}$ - относительная численность $i$-го филотипа (OTE).

Относительное обилие двух технических повторностей объединялось для анализа бактериального сообщества на основе пузырьковых диаграмм. Анализ основных компонентов и кластерный анализ выполняли с помощью статистического пакета Past3 [Hammer et $a l ., 2001]$ с использованием алгоритма невзвешенных парных групп со средним арифметическим (UPGMA) и индекса евклидова расстояния в качестве индекса сходства.

Идентификация изолятов по последовательностям гена 16 S рРНК. Очистка ДНК (http://evrogen. ru/kit-user-manuals/BC023.pdf), ПЦР со стандартными праймерами 27f (5'-AGAGTTTGATCMTGGCTCAG-3') и 1492r (5'-TACCTTGTTACGACTT-3') [Lane, 1991] по программе $96^{\circ} \mathrm{C}-5$ мин $\left(96^{\circ} \mathrm{C}-10 \mathrm{c}, 60^{\circ} \mathrm{C}-20 \mathrm{c}, 72^{\circ} \mathrm{C}-\right.$ 1.5 мин), 20 циклов, $72{ }^{\circ} \mathrm{C}-1$ мин, а также определение последовательностей $16 \mathrm{~S}$ рРНК выполнены в ООО «Евроген» (г. Москва, Россия). Последовательности были отредактированы в программе Chromas (https:// chromas.software.informer.com) и выровнены между собой с помощью программы Clustal Omega (https:// www.ebi.ac.uk/Tools/msa/clustalo). Поиск гомологов проводили с помощью программы BLAST в базе данных GenBank (https://blast.ncbi.nlm.nih.gov/Blast.cgi). Филогенетический анализ выполнен с использованием программного обеспечения MegaX [Kumar et al., 2018] с помощью алгоритма максимального правдоподобия по модели Тамура-Нея [Tamura, Nei, 1993].

Размещение нуклеотидных последовательноcmeй в GenBank. Последовательности V4 региона 16S pРНК были депонированы в базу данных NCBI как bioproject PRJNA625477, а последовательности генов $16 \mathrm{~S}$ рРНК изолятов - в базу данных NCBI под номерами MN599988-MN599993.

\section{ПОЛУЧЕННЫЕ РЕЗУЛЬТАТЫ}

Метан в кернах скв. 7 в районе м. Финнесет. Содержание метана в кернах скв. 7 варьировало от $0.00524 \pm 0.00007$ до $0.75572 \pm 0.00426$ мл/кг (см. рис. 2). Значение $\delta^{13} \mathrm{C}$ для метана в образце с глубины 2.3 м 
Таблица 1. Радиоуглеродное датирование органического вещества образцов скв. 7

\begin{tabular}{c|c|c|c|c|c|}
$\begin{array}{c}\text { Глубина } \\
\text { образца, м }\end{array}$ & $\begin{array}{c}\text { Общее } \\
\text { содержание } \\
\text { углерода } \\
\text { в образце, мкг }\end{array}$ & $F^{14} \mathrm{C}$, абс. & $\begin{array}{c}{ }^{14} \mathrm{C} \text {-возраст, } \\
\text { лет ДНВ }\end{array}$ & $\begin{array}{c}\text { Калиброванный } \\
\text { средний возраст, } \\
\text { кал. лет ДНВ }\end{array}$ & $\begin{array}{c}\text { Калиброванный возрастной } \\
\text { промежуток }(2 \sigma), \\
\text { кал. лет ДНВ }\end{array}$ \\
\hline 8.9 & 181 & $0.20 \pm 0.00$ & $12844 \pm 105$ & 15340 & $15030-15720$ \\
11.6 & 25 & $0.62 \pm 0.01$ & $3885 \pm 74$ & 4310 & $4140-4450$ \\
\hline
\end{tabular}

Таблица 2. Общее количество клеток и количество КОЕ в 1 г мерзлоты на средах 1/5TSA и R_A в исследуемых образцах

\begin{tabular}{c|cc|c|c|c} 
Скважина & $\begin{array}{c}\text { Глубина } \\
\text { образца, }\end{array}$ & Образец & $\begin{array}{c}\text { Общее количество } \\
\text { клеток }\end{array}$ & $\begin{array}{c}\text { КОЕ в 1 г мерзлоты } \\
(1 / 5 \mathrm{TSA})\end{array}$ & $\begin{array}{c}\text { КОЕ в 1 г мерзлоты } \\
\left(\mathrm{R}_{2} \mathrm{~A}\right)\end{array}$ \\
\hline \multirow{2}{*}{1} & $0-0.05$ & & $8.49 \pm 1.31 \cdot 10^{7}$ & $2.16 \pm 0.00 \cdot 10^{5}$ & $2.16 \pm 0.00 \cdot 10^{5}$ \\
& 1.3 & $\mathrm{~S} 1-1$ & $3.10 \pm 0.35 \cdot 10^{7}$ & $3.03 \pm 0.78 \cdot 10^{2}$ & $1.62 \pm 0.76 \cdot 10^{2}$ \\
\hline \multirow{2}{*}{2} & 3.9 & & $9.24 \pm 0.94 \cdot 10^{6}$ & $3.96 \pm 0.27 \cdot 10^{3}$ & $5.47 \pm 1.87 \cdot 10^{3}$ \\
& 4.2 & $\mathrm{~S} 2-4$ & $1.26 \pm 0.28 \cdot 10^{7}$ & $6.15 \pm 2.90 \cdot 10^{1}$ & $1.58 \pm 0.67 \cdot 10^{3}$ \\
\hline \multirow{2}{*}{5} & 3.0 & & $1.32 \pm 0.18 \cdot 10^{7}$ & $6.20 \pm 0.45 \cdot 10^{4}$ & $6.20 \pm 0.46 \cdot 10^{4}$ \\
& 3.1 & $\mathrm{~S} 5-3$ & $3.37 \pm 0.19 \cdot 10^{7}$ & $2.86 \pm 0.21 \cdot 10^{3}$ & $2.06 \pm 0.35 \cdot 10^{3}$ \\
\hline \multirow{2}{*}{7} & 1.8 & & Нет данных & $2.07 \pm 0.33 \cdot 10^{2}$ & $1.77 \pm 0.75 \cdot 10^{3}$ \\
& $4.5-4.7$ & & $1.65 \pm 0.47 \cdot 10^{7}$ & $1.61 \pm 0.26 \cdot 10^{2}$ & $3.60 \pm 0.00 \cdot 10^{1}$ \\
& 6.5 & $\mathrm{~S} 7-7$ & $6.73 \pm 0.73 \cdot 10^{6}$ & Нет данных & Нет данных \\
& 8.6 & $\mathrm{~S} 7-9$ & $8.41 \pm 2.42 \cdot 10^{6}$ & Нет данных & Нет данных \\
& 11.7 & $\mathrm{~S} 7-12$ & $2.61 \pm 0.47 \cdot 10^{7}$ & $1.2 \pm 0.56 \cdot 10^{1}$ & 0 \\
\hline
\end{tabular}

составляло от -51.71 до $-52.03 \%$ VPDB, а для $\mathrm{CO}_{2}-$ от -17.31 до $-18.44 \%$ VPDB.

Радиоуллеродное датирование и общее содержание органического углерода. Среднее значение калиброванного возраста образца, отобранного с глубины 8.9 м в скв. 7, составило 15340 лет, а с глубины 11.6 м 4310 лет до нашего времени (ДНВ) (табл. 1). Принимая во внимание влияние резервуарного эффекта, оцененное для морских отложений на Шпицбергене, истинный возраст может быть на 400 лет меньше расчетного [Mangerud, 1972]. Содержание органического углерода составляло от 0.85 до $0.92 \%$ в скв. 2 и от 0.84 до 1.01 мас. $\%$ - в скв. 7 (см. рис. 2).

Общее содержсание прокариотных клеток и численность культивируемых аэробных бактерий. Общее количество клеток в образцах вечной мерзлоты составляло от $6.73 \pm 0.73 \cdot 10^{6}$ до $3.37 \pm 0.19 \cdot 10^{7}$ клеток в 1 г мерзлоты и $8.49 \pm 1.31 \cdot 10^{7}$ клеток в 1 г - для почвы. Количество аэробных бактерий в горизонтах вечной мерзлоты колебалось от $1.2 \pm 0.56 \cdot 10^{1} \mathrm{KOE}$ (КОЕ - колониеобразующие единицы) в 1 г мерзлоты на среде $1 / 5$ TSA до $6.20 \pm 0.45 \cdot 10^{4} \mathrm{KOE} \mathrm{в} 1$ г мерзлоты на среде $\mathrm{R}_{2} \mathrm{~A}$. Исключение составляет обр. S7-12, в котором KOE на среде $\mathrm{R}_{2} \mathrm{~A}$ выявлено не было. В почве из сезонно талого слоя в районе скв. 1 на обеих средах количество аэробных бактерий составляло $2.16 \pm 0.00 \cdot 10^{5}$ КОЕ в 1 г почвы (табл. 2). Разнообразие колоний на чашках было небольшим и варьировало от одного до трех морфологических типов колоний белого, бежевого, желтого и красного цвета.

Идентификация изолятов аэробных бактерий по гену $16 \mathrm{~S}$ рРНК. Четверо из идентифицированных нами изолятов оказались представителями филума Actinobacteria, семейства Micrococcaceae, родов Arthrobacter и Pseudarthrobacter, а два - представителями класса Betaproteobacteria, семейства Comamonadaceae, рода Rhodoferax, а также класса Gammaproteobacteria, семейства Moraxellaceae, рода Psychrobacter (рис. 3).

Профилирование области V4 16S рРНК. Геномную ДНК удалось выделить из всех шести исследованных образцов: в концентрациях от 0.1 до 0.8 нг/мкл - для образцов скважин 1 и 7 и около 0.02 нг/мкл - для образцов скважин 2 и 5. Содержание архейной ДНК в общей прокариотной ДНК не превышало 1 \% (табл. 3). Среди полученных последовательностей от 0.08 \% (обр. S1-1) до $0.35 \%$ (обр. S7-9) не удалось идентифицировать с использованием программы SILVAngs 1.4 pipeline.

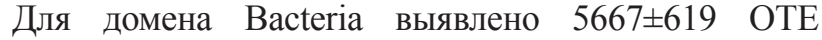
$(3331 \pm 427,159 \pm 18,524 \pm 56,775 \pm 60,95 \pm 35,783 \pm 23$ для образцов S1-1, S2-4, S5-3, S7-7, S7-9, S7-12 соответственно), из которых 105 доминирующих ( $\geq 1 \%$ ) OTЕ $(18,13,19,23,7,25$ соответственно). Всего обнаружено 11 филумов домена Bacteria, причем во всех исследованных образцах преобладали филумы Actinobacteria и Proteobacteria (рис. 4). Доминирующим семейством 


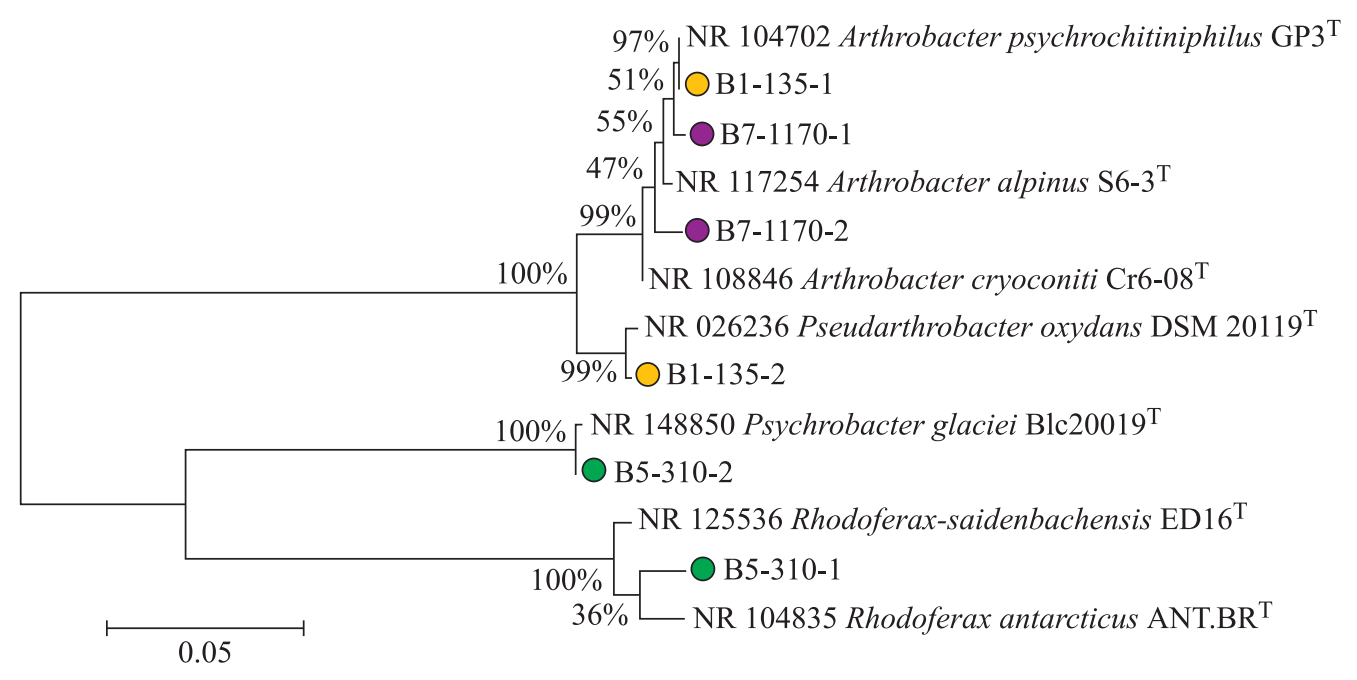

Рис. 3. Филогенетическое положение изолятов из вечной мерзлоты о. Западный Шпицберген возле рудника Баренцбург на основе последовательностей гена $16 \mathrm{~S}$ рРНК между ближайшими типовыми штаммами из базы данных NCBI

Филогенетическое дерево построено методом Maximum Likelyhood на основе модели Тамура-Нея (Tamura-Nei) для 500 реплик в бутстреп-анализе (bootstrap analisys). Шкала внизу дерева отражает количество филогенетически значимых замен нуклеотидов. Названия изолятов соответствуют номеру скважины и глубине керна (см), из которого они были изолированы

Таблица 3. Характеристики ампликоновых библиотек (доля ампликонов домена Archaea, общее количество полученных последовательностей и ОТЕ в образцах, индексы покрытия и разнообразия)

\begin{tabular}{|c|c|c|c|c|c|c|c|c|}
\hline Скважина & $\begin{array}{c}\text { Глубина } \\
\text { образца, } \\
\text { м }\end{array}$ & Образец & $\begin{array}{c}\text { Archaea, } \\
\%\end{array}$ & $\begin{array}{l}\text { ОТЕ, } \\
\text { число }\end{array}$ & $\begin{array}{l}\text { Ампликоны, } \\
\text { количество }\end{array}$ & $\begin{array}{l}\text { Индекс } \\
\text { Гуда, \% }\end{array}$ & $\begin{array}{c}\text { Индекс } \\
\text { Шэннона- } \\
\text { Уивера, \% }\end{array}$ & $\begin{array}{l}\text { Индекс } \\
\text { Чао1, \% }\end{array}$ \\
\hline 1 & 1.3 & S1-1 & 0.04 & $3338 \pm 427$ & $30404 \pm 5471$ & $96.3 \pm 4.3$ & $5.0 \pm 0.1$ & $8540 \pm 1156$ \\
\hline 2 & 4.2 & S2-4 & 1.00 & $164 \pm 18$ & $6678 \pm 604$ & $98.3 \pm 1.1$ & $2.5 \pm 0.1$ & $857 \pm 761$ \\
\hline 5 & 3.1 & S5-3 & 0.02 & $531 \pm 56$ & $19829 \pm 4061$ & $98.7 \pm 0.1$ & $2.8 \pm 0.1$ & $1207 \pm 387$ \\
\hline & 6.5 & S7-7 & 0.02 & $783 \pm 60$ & $14899 \pm 2308$ & $98.2 \pm 0.1$ & $4.7 \pm 0.1$ & $1239 \pm 142$ \\
\hline & 8.6 & S7-9 & 1.00 & $96 \pm 35$ & $164 \pm 32$ & $53.6 \pm 9.6$ & $4.1 \pm 0.6$ & $452 \pm 169$ \\
\hline & 11.7 & S7-12 & 0.14 & $799 \pm 23$ & $10274 \pm 549$ & $96.8 \pm 0.4$ & $4.3 \pm 0.1$ & $1242 \pm 83$ \\
\hline
\end{tabular}

класса Actinobacteria оказалось семейство порядка Actinomycetales - Intrasporangiaceae. Другой широко представленный класс - Thermoleophila - включал в основном семейства Gaiellaceae (33-100 \%) и Solirubrobacterales (3-67\%).

Среди представителей филума Acidobacteria преобладали классы Acidobacteria (6-100 \%), Aminicenantales (3-73.5\%), Holophaga (2.5-41.5\%) и группа Subgroup 6 (8.5-46 \%). Класс Gammaproteobacteria доминировал в обр. S1-1 (43\%), где он состоял из семейства метанотрофных бактерий Methylobacteriaceae (76.5 \%), и в обр. S5-3 (71.5 \%), где 98.5 \% принадлежало семейству Pseudomonadales. Класc Deltaproteobacteria составлял наибольшую долю в обр. S2-4 (0.8 \%), причем 77 \% составляло семейство Desulfobacteracea. Доминирующим семейством класса Betaproteobacteria во всех образцах, кроме обр. S7-9, было семейство Burkholderiaceae (12.5-99.5 \%). Семейство Hydrogenophilaceae (0.0045$1 \%$, на $100 \%$ составляющее класс Betaproteobacteria в образцах S1-1, S5-3, S7-7, и семейство Thiobacillaceae в обр. S7-12 также составили значительную долю. Меньшая доля была представлена семейством Sulphuricellaceae (0.24-38 \%), за исключением обр. S7-12, а также семейством Nitrosomonadaceae (6.5-19\%), за исключением обр. S2-4, семейством Gallionellaceae (4 \% в обр. S1-1, 1.9\% в обр. S7-7 и $6.5 \%$ в обр. S7-9) и семейством Methylophilaceae (8 \% в обр. S1-1 и $1.4 \%$ в обр. S7-7). В классе Alphaproteobacteria преобладали порядок Rhizobiales (25.5-63\%), а также семейства Acetobacteraceae (1.5-42.5\%) и Sphingomonadaceae (2.5-57\%).

Филум Bacteroidetes в основном представлен классом Bacteroidia (во всех выборках - 50-100\%).

Филум Chlorobi представлен классом Ignavibacteria (в обр. S1-1 - $0.9 \%$, обр. S7-7 - $25.5 \%$, обр. S7-12 $8 \%$, в обр. S7-12 - полностью представлен группой OPB56, в обр. S7-7 - группой BSV26 (93 \%). В обр. S1-1 50 \% класcа Ignavibacteria составлен группой BSV26, 


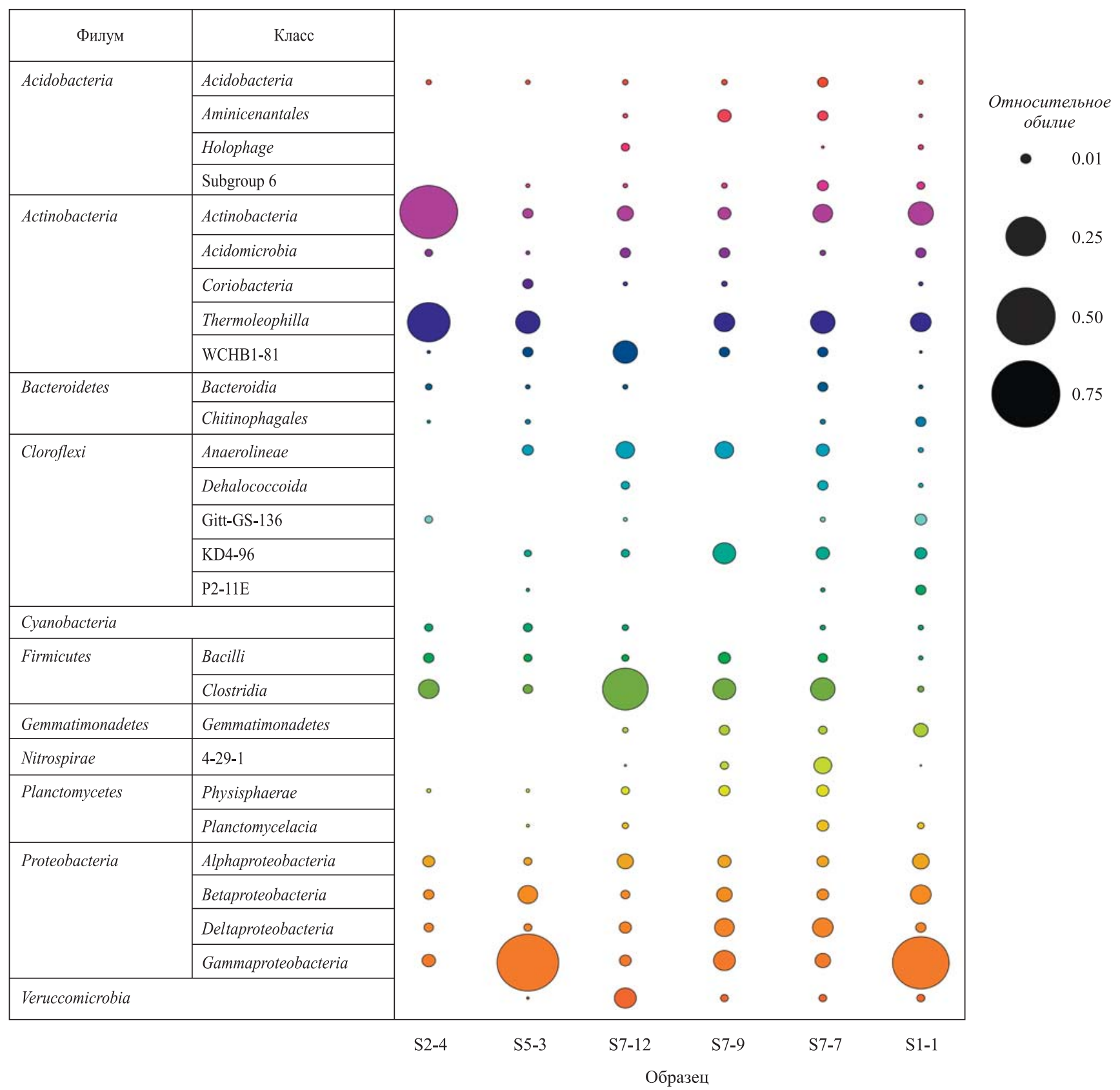

Рис. 4. Относительное обилие таксономических групп доминирующих ( $\geq 1 \%)$ классов домена Васteria в исследованных образцах

Здесь и на рис. 6 кружки - среднее значение относительного обилия таксономических групп по двум техническим повторностям

а группы OPB56 и PHOS-HE36 представлены по $25 \%$ каждая.

Филум Chloroflexi представлен в исследованных образцах классами KD4-96 (0-61\%), Gitt-GS136 (обр. S1-1 - 30 \%, обр. S2-4-73.5\%), P2-11E (обр. S1-1$16 \%$, обр. S5-3 - $1 \%$ ), OLB14 (S1-1- $7 \%$ ), Chloroflexia (обр. S1-1 - $3 \%$, обр. S2-4 - $16 \%$ и обр. S7-12 - 1.5\%), Anaerolineae (2.5-81.5\%) и Dehalococcoida. (обр. S1-1$0.95 \%$, обр. S7-7 - $12 \%$ и обр. S7-12 - $7.5 \%$ ).

Филум Planctomycetes присутствовал во всех образцах в количестве 0.005-3 \%. В образцах S1-1, S7-7 и S7-12 он был в основном представлен классом
Planctomycetacia (89\%, 68.5\%, $53.5 \%$ соответственно), в обр. S2-4 - на 100 \% классом OM190, в обр. S7-7 - на 71.5 \% классом SM1A02, а в обр. S7-9 - на 100 \% классом Phycisphaerae.

Филум Firmicutes представлен в основном классами Bacilli и Clostridia. Класс Bacilli составил $19 \%$ филума в обр. S1-1, включая в себя $16 \%$ семейства Lactobacillaceae. Это же семейство составляло $3 \%$ Bacilli в обр. S2-4, которое, в свою очередь, составляло $11 \%$ от Firmicutes, тогда как в обр. S5-3 оно было доминирующим в порядке Lactobacillales, где Bacilli составляли 38 \% от Firmicutes. Порядок Lactobacillales 
также был представлен семейством Carnobacteriaceae (10\% для обр. S1-1, $13.5 \%$ - для обр. S7-7 и $53 \%$ для обр. S7-12). Класс Clostridia в основном был представлен порядком Clostridiales (96.5-100 \%). Среди его представителей род Desulfosporosinus семейства Peptococcaceae был обнаружен во всех исследованных образцах и составлял 5-75 \% от класса Clostridia. Представители группы Family XI присутствовали в образцах S1-1, S2-4 и S7-12, где составили 3, 0.3 и $43 \%$ соответственно. В обр. S7-12 было обнаружено семейство Caldicoprobacteriaceae $(14.5 \%$ от класса Clostridia).

Филум Gemmatimonadetes составлял наибольшую долю в образце S1-1, но также был обнаружен в скв. 7 (0.25-1 \%). Класс Gemmatimonadetes составлял 100 \% в обр. S1-1 и 61 \% в обр. S7-12. В обр. S7-9 16.5 \% класса приходилось на морскую бентосную группу PAUC43f, а в обр. S7-12 - 27 \% на семейство Longimicrobiaceae.

Представители филума Cyanobacteria были обнаружены только в образцах S1-1, S2-4, S7-7 и S7-12. В образцах S2-4 и S7-7 они были представлены только семейством Gastranaerophilales, а в обр. S7-12 - семействами Nostocaceae и Leptolyngbyaceae (по 43.5 \%).

Филум Nitrospirae был обнаружен во всех исследованных образцах. В образцах S1-1 и S7-12 он был представлен в основном семейством Nitrospirae $(99.5$ и $54 \%$ соответственно). Другим представителем филума в этих образцах была группа 4-29-1 (0.45 \% в обр. S1-1 и 5.5 \% в обр. S7-12). В обр. S2-4 филум был представлен одним семейством Thermodesulfovibrionia. B обр. S5-3 также преобладала только одна группа BMS9AB35. В образцах S7-7 и S7-9 доминировали группа 4-29-1 (65 и $15 \%$ соответственно) и семейство Thermodesulfovibrionia (34 и $85 \%$ соответственно).

Филум Candidatus Atribacteria представлен группой JS1, которая доминировала в обр. S7-12 (12 \%) и была обнаружена в небольшой доле в образцах S1-1 (0.005\%), S2-4 (0.25\%), S5-3 (0.065\%) и S7-7 (0.075\%).

Минорные компоненты для образцов S1-1, S2-4, S5-3, S7-7, S7-9 и S7-12 составляли 4.47, 3.46, 2.98, 12.93, 7.80 и $4.70 \%$ от общего разнообразия соответственно. Они были представлены филумами Caldeserica, Chlamydiae, Deinococcus-Thermus, Patesibacteria и Veruccomicrobia.

\section{ОБСУЖДЕНИЕ РЕЗУЛЬТАТОВ}

Содержание и происхождение метана в скв. 7 $\boldsymbol{y}$ м. Финнесет. Полученные значения $\delta^{13} \mathrm{C}$ (VPDB) для метана соответствуют его термогенному или термогенно-микробному происхождению [Шакиров и др., 2014]. Значения $\mathrm{CO}_{2}$ лежат в диапазоне ниже значений, характерных для метаболического диоксида углерода, и выше значений, характерных для мантийного и атмосферного $\mathrm{CO}_{2}$ [Юдович, Кетрис, 2010]. По данным [Hitchman et al., 1990], эти значения попадают в диапазоны для метана биогенного (от -40 до -109 \%о для глубоководных отложений, озерных отложений, болот и маршей) и термогенного (от -12 до -71 \%о для угольных пластов) генезиса, а по данным [Тараник, 2017], - к диапазонам, полученным для газов в угольных шахтах Донбасса. Мы полагаем, что метан из скв. 7 мог попасть в четвертичные осадочные породы из нижележащих угленосных скальных грунтов. Это предположение может объяснить пограничное значение $\delta^{13} \mathrm{C}$ (VPDB) для метана, обнаруженного в образце с глубины 2.3 м, между метаном биохимического генезиса (от -50 до -80\%о) и метаном из газонефтяных месторождений (от -30 до -50 \%о) [Тараник, 2017]. Выходы природного газа вместе с жидкими углеводородами на м. Финнесет наблюдались в 1911 г. [Senger et al., 2019], что также подтверждает возможность наличия термогенного метана в образцах вечной мерзлоты, вскрытой скв. 7.

Радиоуалеродное датирование и данные об общем содержсании органического углерода. Полученные датировки четвертичных многолетнемерзлых пород в скв. 7 подтверждают, что морские террасы в районе Баренцбурга имеют возрастной диапазон от позднего плейстоцена до голоцена. Общее количество органического углерода в образцах из скважин 2 и 7 соизмеримо с общим содержанием углерода (в основном состоящего из ТОС). Общее содержание ТОС невелико и едва превышает 1 мас. \%. Результаты анализа содержания органического углерода показали его равномерное распределение по скважинам, т.е. выявленные различия в микробиологических характеристиках мерзлоты не являются следствием вариаций содержания органического углерода.

Общая численность клеток и численность культивируемых аэробных бактерий. Общее количество бактерий в почве и вечной мерзлоте в районе Баренцбурга оказалось больше, чем в приповерхностном слое вечной мерзлоты в Ню-Олесунне на глубине 1.8 м (1.14 $10^{5}-3.98 \cdot 10^{6}$ клеток в 1 г образца) [Singh et $a l ., 2017]$, и меньше, чем в современных морских отложениях (от 2.1 до $4.7 \cdot 10^{9}$ клеток на 1 мл влажного осадка фьорда Смееринбург [Ravenschlang et al., 2001] и от $2 \cdot 10^{8}$ до $4 \cdot 10^{9}$ клеток на 1 мл влажного осадка вблизи о. Западный Шпицберген, Северный Ледовитый океан, и в районе о. Тромсёйя, север Норвегии [Sahm, Berninger, 1998]).

Количество культивируемых аэробных бактерий, полученное нами в мерзлых отложениях морского происхождения, сопоставимо с таковым, полученным при $10{ }^{\circ} \mathrm{C}$ в донных морских отложениях в районе Ню-Олесунна - $10^{3}-10^{4} \mathrm{KOE} \mathrm{в} 1$ г мерзлоты [Srinivas et al., 2009], а значения численности для почвы были сопоставимы с таковыми для почв Ню-Олесунна, где они варьировали от $10^{3}$ до $10^{6} \mathrm{KOE} \mathrm{в} 1$ г почвы [Singh et al., 2017]. Полученные значения КОЕ/г для мерзлых пород Шпицбергена оказались меньше, чем для изученных ранее с использованием схожих питательных сред и температур культивирования мерзлых отложений Колымской низменности [Хлебникова и дp., 1990; Vishnivetskaya et al., 2000] и Гыданского полуострова [Демидов и др., 2016а], но ближе по порядку к таковым в мерзлоте антарктических оазисов [Караевская и др., 2017] (рис. 5).

Формирование в прибрежной морской зоне в условиях сноса продуктов криогенного выветривания скальных пород, расчлененный рельеф окружающей суши и наличие на ней ледников сближает условия образования мерзлых осадков на о. Западный Шпицберген и в антарктических оазисах. Напротив, на Гыданском полуострове и Колымской низменности формирование 


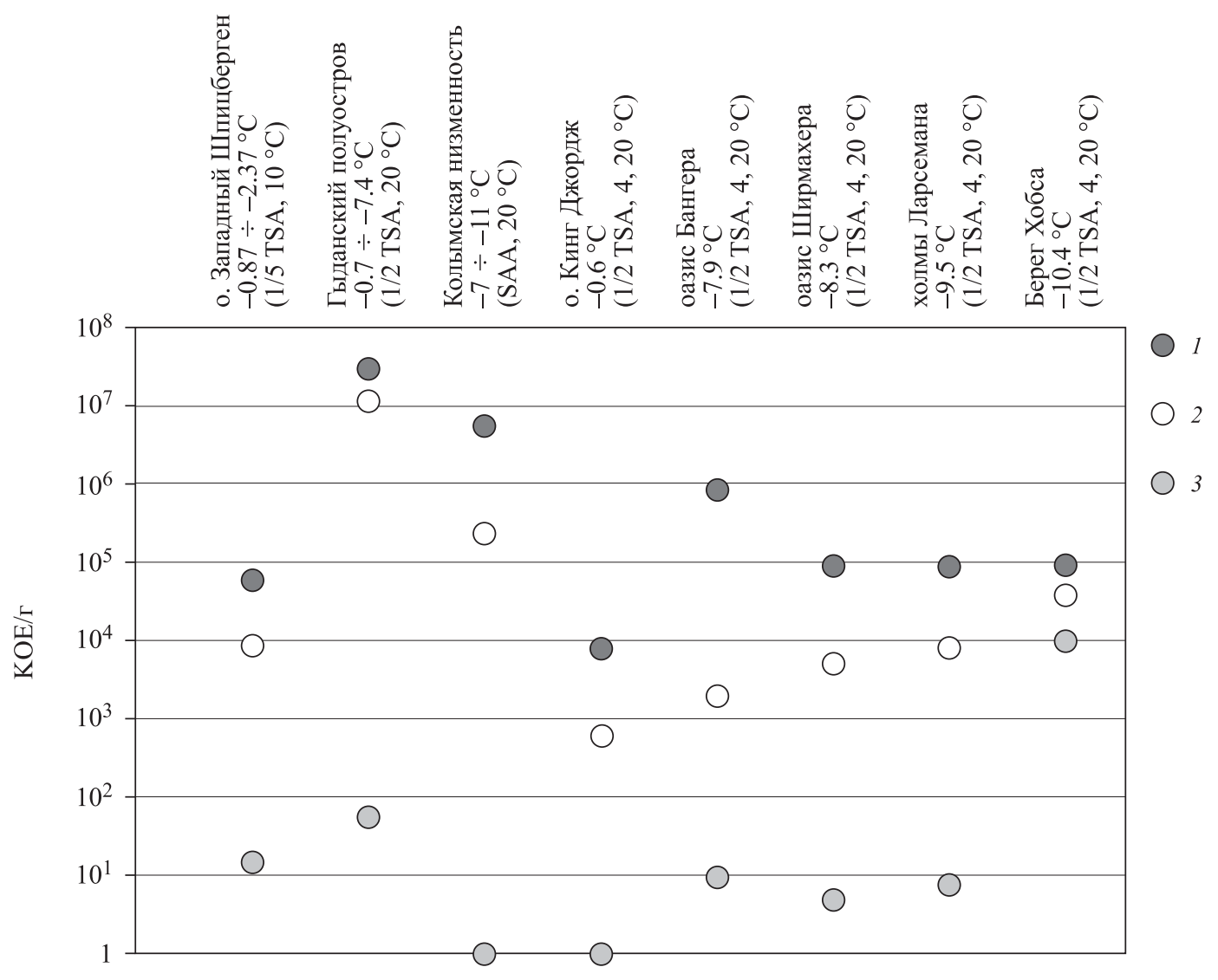

Рис. 5. Численность КОЕ в 1 г мерзлоты культивируемых аэробных бактерий в вечной мерзлоте о. Западный Шпицберген и в мерзлоте других регионов Арктики и Антарктики, полученных с помощью схожих питательных сред и температур культивирования

Численность: 1 - максимальная; 2 - средняя; 3 - минимальная. Под названием района указана среднегодовая температура многолетнемерзлых пород, в скобках - температура и среда культивирования. Данные для Колымской низменности взяты из [Хлебникова и др., 1990; Vishnivetskaya et al., 2000], для Гыданского полуострова - из [Демидов и др., 2016а], для Антарктиды - из [Караевская и др., 2017]

осадков происходило на обширных равнинах или на окружающем шельфе.

Примечательно, что наименьшей численностью аэробных бактерий среди арктической мерзлоты обладает наиболее теплая мерзлота о. Западный Шпицберген. Аналогично для Антарктики, наименьшей численностью обладает наиболее теплая мерзлота о. Кинг Джордж [Караевская и др., 2017]. Это может быть связано с тем, что процессы замораживания и оттаивания приводят к сокращению бактериальной численности и обеднению разнообразия мерзлотных микробных сообществ [Schimel et al., 2007]. Морфологическое разнообразие колоний исследованных нами образцов было невелико и сопоставимо с мерзлотой раннеплейстоценовой олерской и томус-ярской свит Колымской низменности [Хлебникова и др., 1990] (1-3 морфологических единицы на образец), тогда как в мерзлоте антарктических оазисов при сопоставимых значениях КОЕ в 1 г мерзлоты она варьировала от 1-3 до 9 морфологических единиц на образец [Караевская и др., 2017].
Изоляты аэробных бактерий. Два из полученных нами изолятов - B1-135-1 (MN599988) и В7-1170-1 (MN599990) - были на $99.8 \%$ и $99.0 \%$ соответственно родственны типовому штамму GP3 ${ }^{\mathrm{T}}$ Arthrobacter psyrochitiniphilus, выделенному из субантарктических почв, способному гидролизовать хитин при $10{ }^{\circ} \mathrm{C}$ [Wang et al., 2009]. Изолят B1-135-2 (MN599992) на 99.8 \% сходен с выделенным из субантарктических вод типовым штаммом DSM $20119^{\mathrm{T}}$ Pseudarthrobacter oxydans, обладающим протеиназной активностью при $5{ }^{\circ} \mathrm{C}$ [Reddy et al., 2009]. Изолят В7-1170-2 (MN599991) на $99.8 \%$ сходен с типовым штаммом S6-3 $3^{\mathrm{T}}$ Arthrobacter alpinus, выделенным из альпийской почвы [Zhang et al., 2010]. Изолят В5-310-1 на 97.5 \% сходен с типовым штаммом ED16 ${ }^{\mathrm{T}}$ пурпурной несерной бактерии Rhodoferax saidenbachensis, выделенным из отложений водохранилища в Саксонии [Kaden et al., 2014]. Изолят В5-310-2 на 99.1 \% сходен со штаммом Blc20019 ${ }^{\mathrm{T}}$ Psychrobacter glaciei, который был выделен из альпийской почвы и из почв о. Аделида в Субантарктике [Zeng et al., 2016; Romaniuk et al., 2018]. Все эти рода обнаружены в соответствующих 
образцах согласно анализу области V4 гена $16 \mathrm{~S}$ рРНК и составляют от домена Bacteria соответственно $0.65 \%$ (Arthrobacter) и $0.1 \%$ (Pseudarthrobacter) в обр. S1-1 и по 0.035 \% (Psychrobacter и Rhodoferax) в обр. S5-3 и (Arthrobacter) в обр. S7-12 (см. рис. 3). В литературе, посвященной культивируемому разнообразию аэробных бактерий морских донных отложений у о. Западный Шпицберген, описаны представители различных родов аэробных бактерий с преобладанием представителей Pseudomonas, Psychrobacter и Arthrobacter [Srinivas et al., 2009; Konieczna et al., 2011]. Эти виды могли попасть в исследуемые многолетнемерзлые породы из почв и пресных водоемов архипелага.

Характеристика ампликоновых библиотек. Наибольшим разнообразием характеризовался обр. S1-1 - его индекс Шэннона-Уивера составил $5.0 \pm 0.1$, индекс Чао $1-8540 \pm 1156$, а индекс покрытия библиотеки $-96.3 \pm 4.3 \%$ (см. табл. 3 ). Образцы из скв. 7 обладали меньшим прокариотным разнообразием для них индекс Шэннона-Уивера составлял от 4.1 \pm 0.6 до 4.7 \pm 0.1 , а Чао1 - от $452 \pm 169$ до $1242 \pm 83$. Обр. S7-9 с самыми низкими индексами разнообразия и покрытия библиотеки (53.6 \pm 9.6 \%) выделяется из общей картины (в образцах S7-7 и S7-12 индекс покрытия библиотеки варьировал в пределах 96.8 $\pm 0.4-98.2 \pm 0.1 \%$ ). Это явление может быть объяснено менее благоприятными условиями для сохранения ДНК в месте отбора образца, а также высоким содержанием растительных остатков в обр. S7-9. Образцы S2-4 (2.5 \pm 0.1$)$ и S5-3 (2.8 \pm 0.1$)$ характеризовались наименьшим разнообразием по индексу Шэннона-Уивера, тогда как покрытие библиотеки в них было довольно высоким и составляло $98.3 \pm 1.1$ и $98.7 \pm 0.1$ соответственно. Это может быть связано с очень низкими выходными концентрациями ДНК, а это, в свою очередь, с их более древним возрастом по сравнению с образцами нижних морских террас, вскрытых скважинами 1 и 7.

Таксономия доминирующих ОТЕ домена Bacteria. Рассмотрим таксономию ОТЕ, составляющих $>1.5 \%$ в ампликоновых библиотеках домена Bacteria (рис. 6, табл. 4).

Образцы S1-1 и S2-4 характеризовались доминированием бактерий класса Actinobacteria семейства Intrasporangiaceae и рода Oryzihumus, близкородственных типовому аэробному штамму Oryzihumus soli Aerobe- $19^{\mathrm{T}}$ (см. табл. 4), растущему при $15-30{ }^{\circ} \mathrm{C}$

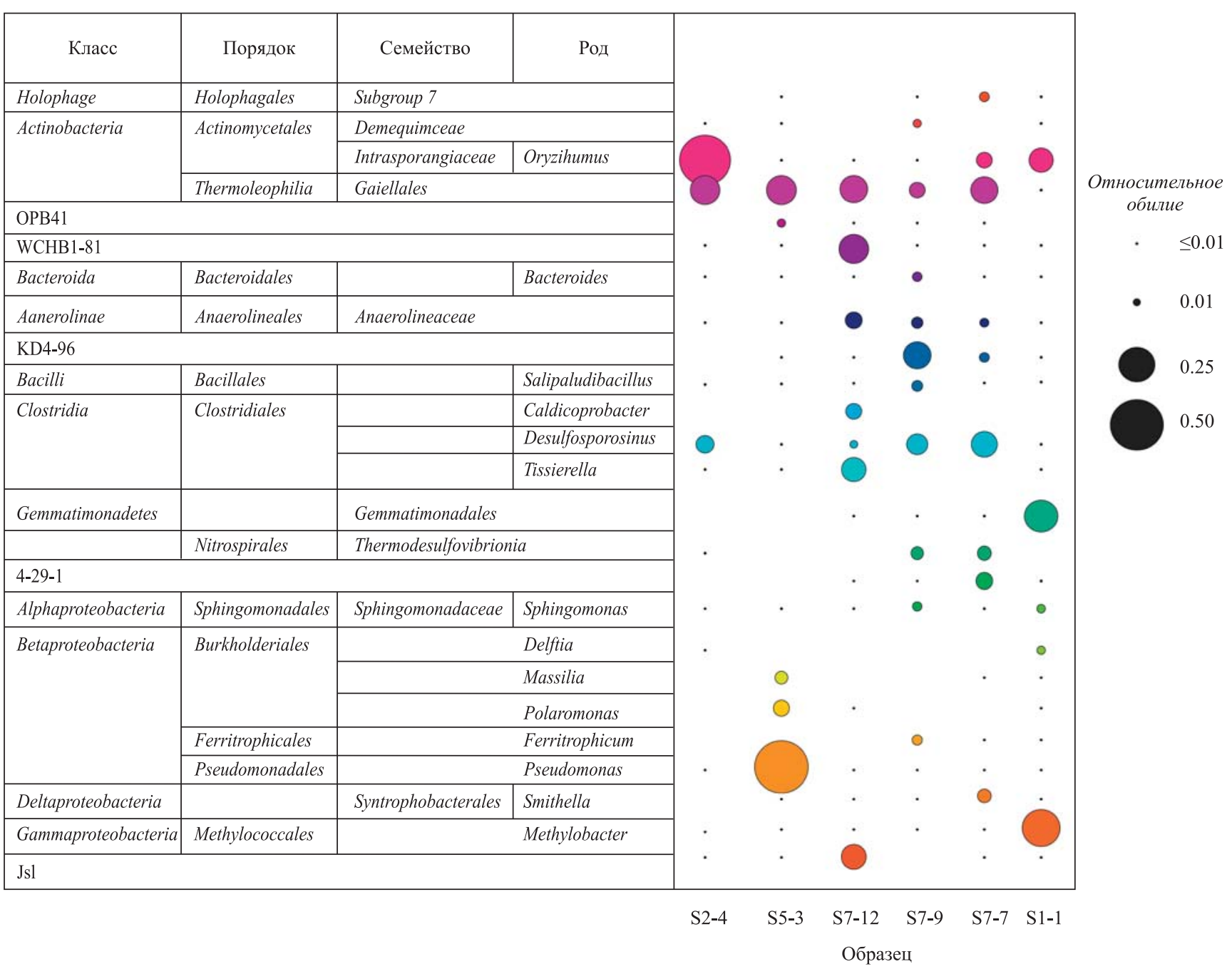

Рис. 6. Относительное обилие таксономических групп доминирующих ( $\geq 1 \%$ ОТЕ домена Васteria в исследованных образцах и их таксономическое положение (среднее значение относительного обилия по двум техническим повторностям) 


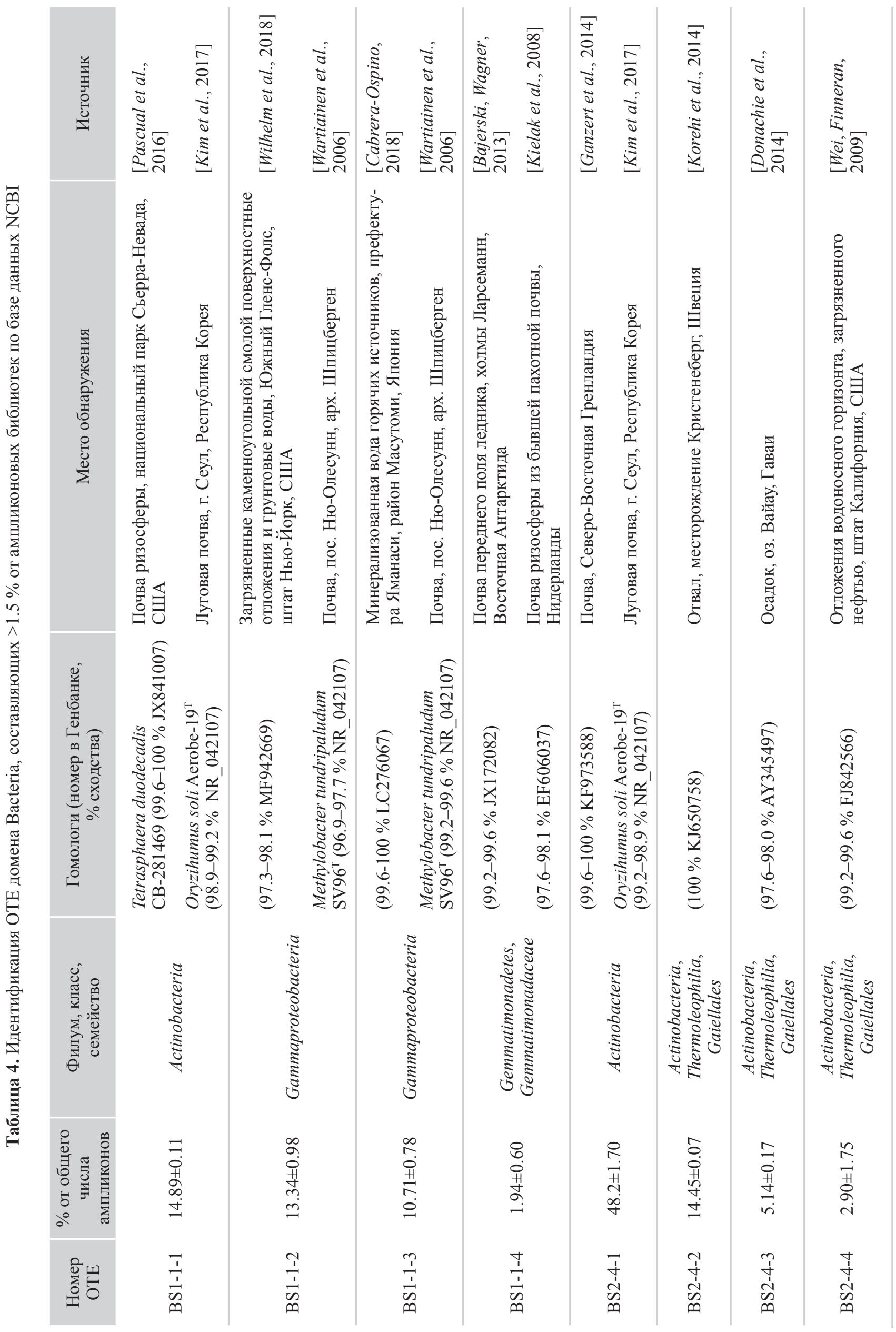


Бактериальные сообщества мерзльх четвертичных пород морского генезиса...

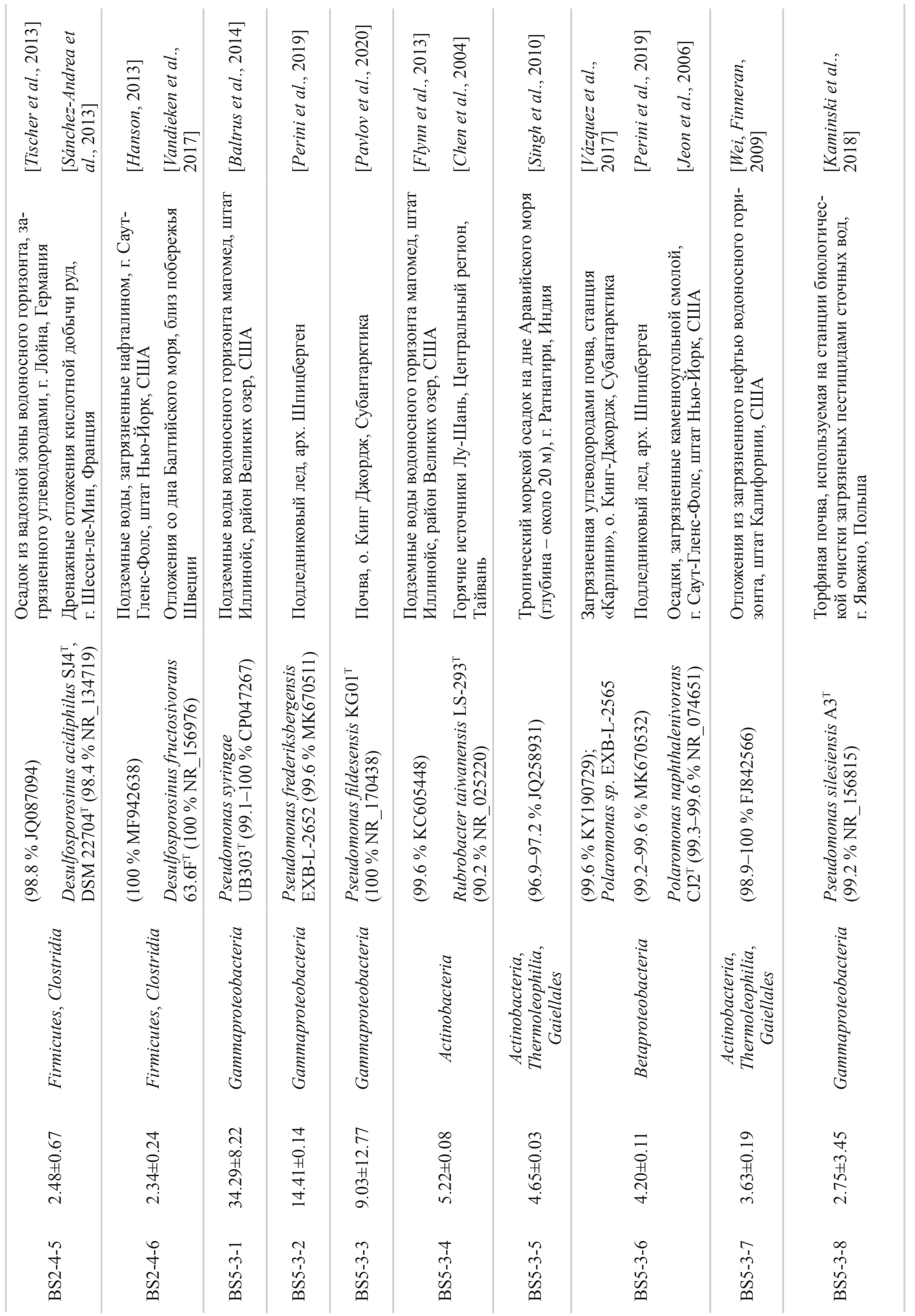




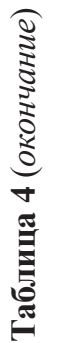

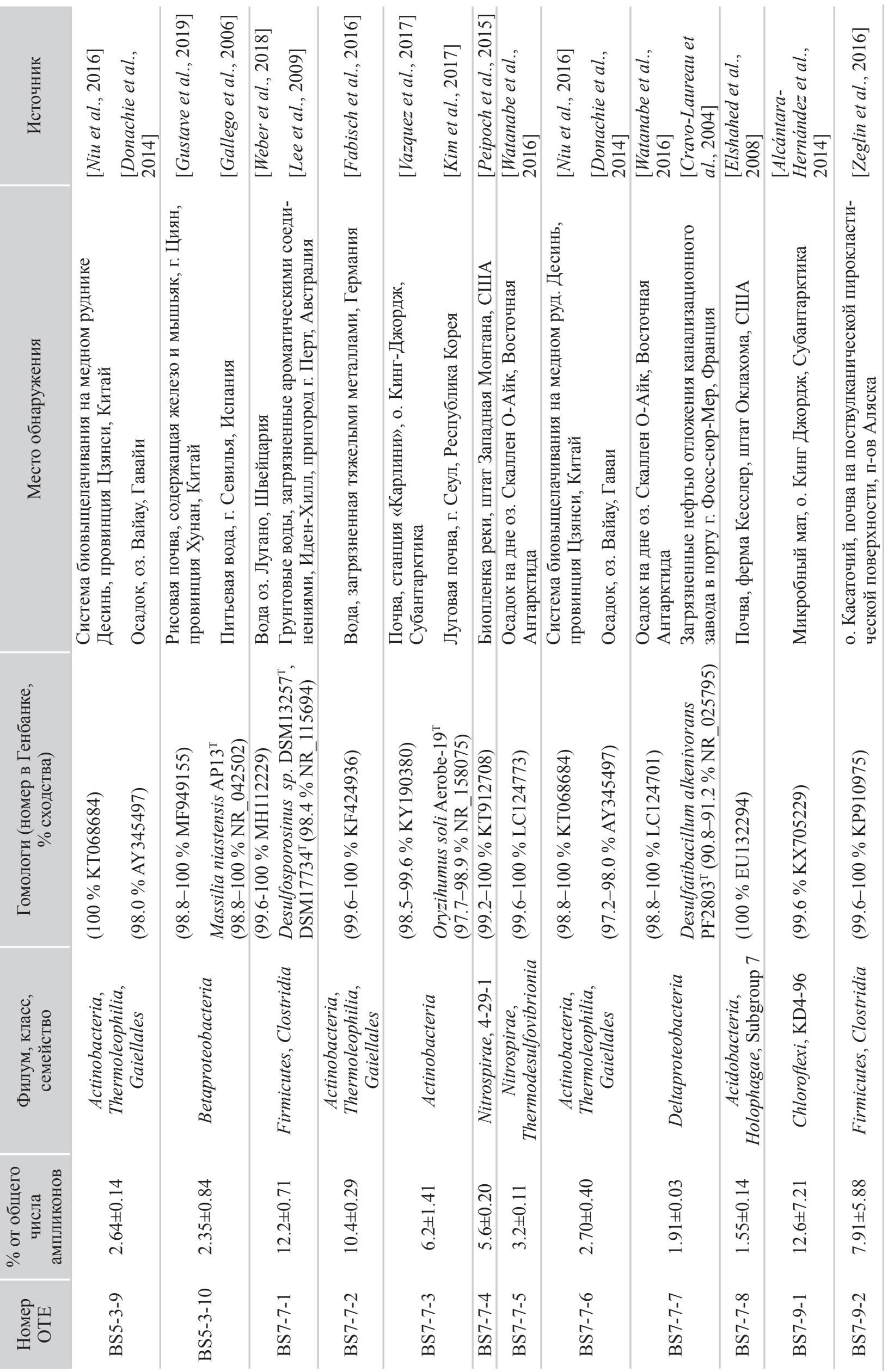


Бактериальные сообщества мерзльх четвертичных пород морского генезиса...

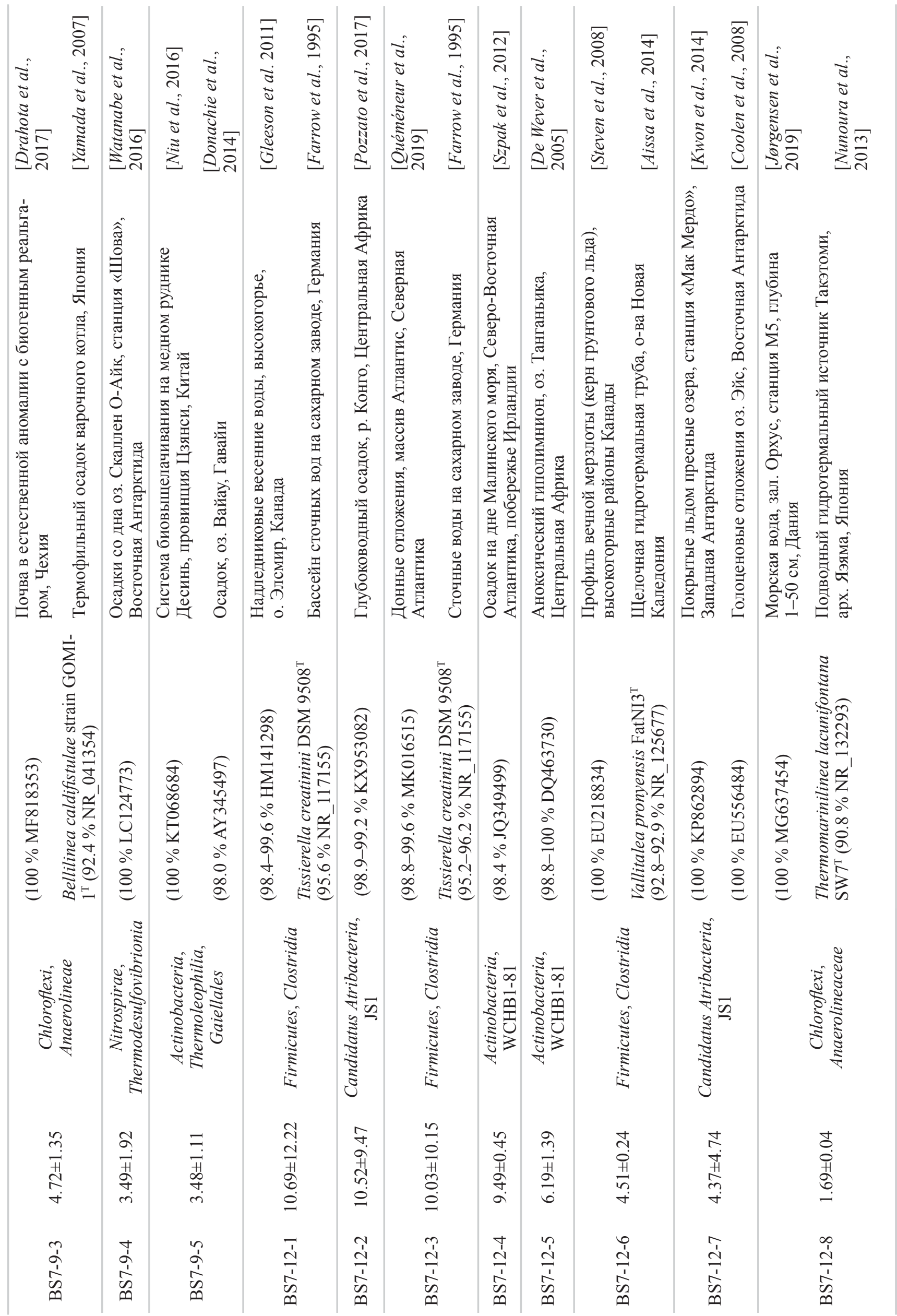


и рН 5-7, гидролизующему целлюлозу, желатин, эскулин, производящему эстеразу $(\mathrm{C} 4, \mathrm{C} 8)$ и липазу (C8) и восстанавливающему нитрат до нитрита [Kim et al., 2017].

Обр. S1-1, кроме того, отличался доминированием представителей класса Gammaproteobacteria, наиболее родственным типовому штамму метилотрофной бактерии Methylobacter tundripaludum SV96 ${ }^{\mathrm{T}}$ и имеющим наибольшее сходство с клонами, обнаруженными в водах, загрязненных отходами угольной промышленности, а также в японских горячих источниках (см. табл. 4). Филум Gemmatimonadetes, в большом количестве присутствующий в обр. S1-1, включает обитателей почв и сточных вод. У его представителей обнаружен центр фотосистемы II [Zeng et al., 2015; Zeng, Kobližek, 2017].

Порядок Thermoleophila, доминировавший в образцах S2-4, S5-3, S7-7, S7-9 и S7-12, представлен семейством Gaiellaceae, единственный типовой представитель которого - Gaiella occulata F2 233 ассимилирующий некоторые сахара, растущий при 15$45^{\circ} \mathrm{C}$, и $\mathrm{pH} 5-9$, и содержании $\mathrm{NaCl}$ менее $1 \%$, восстанавливающий нитрат до нитрита) - был обнаружен в глубоких минеральных водах Португалии [Albuquerque et al., 2011].

Доминирующие ОTE обр. S5-3 из класса Gammaproteobacteria представлены семейством Pseudomonadaceae, ряд членов которого встречается в морских местообитаниях [Fendrich, 1988]. Ближайшие доминирующим в образце ОТЕ клоны были обнаружены в подземных, подледниковых водах и субантарктических почвах, также подверженных загрязнению углеводородами и тяжелыми металлами (см. табл. 4).

Наибольшую долю во всех образцах скв. 7 составлял класс Deltaproteobacteria, включающий большинство сульфатредуцирующих бактерий. Род Desulfovibrio представлен сульфатредуцирующими аэротолерантными бактериями водных экосистем [Kuever et al., 2015].

Филум Nitrospirae доминировал в образцах S7-7 и S7-9, где был представлен порядком Nitrospirales и ceмейством Thermodesulfovibrionia.

Среди представителей класса Clostridia стоит отметить род Desulfosporosinus, доминировавший в образцах S2-4, S7-7 и S7-9. Это обитатели загрязненных углеводородами пресных и морских вод (см. табл. 4), являющиеся облигатными гетеротрофами и использующие в качестве акцептора электронов серу, тиосульфат и сульфиты.

Филум Chloroflexi, включающий аэробных термофилов, анаэробных фототрофных бактерий и галогенофилов [Gupta et al., 2012], доминировал в скв. 7, будучи представленным семейством Anaerolinaceae класса Anaerolinae. В свою очередь, класс KD4-96 филума Chloroflexi, доминировавший в обр. S7-9, был обнаружен в холодной влажной луговой почве альпийской тундры в Скалистых горах Колорадо [Costello, Schmidt, 2006]; он также часто встречается в почвах, загрязненных металлами [Golebiewski et al., 2014], где его содержание коррелирует с концентрациями железа и алюминия [Wegner, Liesack, 2017].

В обр. S7-12 доминировали ОTЕ, принадлежащие к порядку Clostridiales, роду Tissierella. Они оказались наиболее близкими к типовому штамму T. creatinini
DSM 9508 ${ }^{\mathrm{T}}$, способному расщеплять креатинин [Farrow et al., 1995; Harms et al., 1998]. Также значительную долю в образце составляли OTE группы JS1, принадлежащей к филуму Candidatus Atribacteria, широко распространенному в анаэробных осадках, богатых метаном, включая глубоководные отложения бассейна Адель в Восточной Антарктиде [Carr et al., 2015]. Помимо этого, существенную долю в образце составили представители филума Actinobacteria группы WCHB1-81, распространенные в пресных водах, в том числе загрязненных метаном [Inceoglu et al., 2015], углеводородами и хлорированным растворителем [Dojka et al., 1998], а также цианотоксинами [Dziga et al., 2019].

Генетическая взаимосвязь образцов и интерпретация биохимической роли сообщества. На основе анализа главных компонент по разнообразию бактериальных филумов установлено, что наиболее близки между собой образцы S7-7 и S7-12, несколько отличен от них обр. S7-9. Отличие обр. S7-9 можно объяснить повышенным содержанием в нем фрагментов растительного материала, что, скорее всего, связано с условиями седиментации. Другой кластер образован образцами S1-1 и S5-3 (рис. 7). Обр. S2-4 отличался от других образцов. Это может быть связано с различными условиями формирования и разным возрастом отложений скважин 1-7 и скв. 2.

По составу доминирующих филумов домена Bacteria образцы скважин 5 и 7 схожи с образцами наземной и подводной мерзлоты на м. Мамонтов Клык, в которых преобладали филумы Actinobacteria (класс Thermoleophilia), Chloroflexi (Gitt-GS-136, KD4-96), Firmicutes (класс Clostridia), Gemmatimonadae, а в образцах на границе вечной мерзлоты и активных слоев были обнаружены Alpha-, Betaproteobacteria, а также Candidatus Atribacteria [Mitzscherling et al., 2017, 2019]. Особенностью скв. 7 является наличие в ее образцах S7-7 и S7-9 доминирующих (>3 \%) OTE филума Nitrospirae (семейство Thermodesulfovibrionia), которые, по-видимому, участвуют в процессе сульфатредукции. В свою очередь, обр. S2-4 сходен по бактериальному разнообразию с толщей замерзшего в позднем голоцене лёсса долины Адвентдален [Müller et al., 2018] по доминированию филума Actinobacteria (семейство Intrasporangiaceaе и класс Thermoleophilia).

Согласно литературным данным, филумы Proteobacteria, Firmicutes, Chloroflexi, Acidobacteria, Actinobacteria и Bacteroidetes также в основном распространены в активном слое и толщах вечной мерзлоты Арктики [Jansson, Taş, 2014; Taş et al., 2018]. Представители филумов Actinobacteria, Chloroflexi, Firmicutes, Gemmatimonadetes и Proteobacteria проявляли активность при отрицательных температурах [Tuorto et al., 2014; Coolen, Orsi, 2015]. Betaproteobacteria и Firmicutes ранее считались наиболее приспособленными к жизни при низких температурах и низком содержании питательных веществ группами. Представители филума Firmicutes способны образовывать споры, что также объясняет их значительную долю в мерзлотных экосистемах [Johnson et al., 2007]. Было показано, что представители Candidatus Atribacteria из газогидратных осадков выживают при высоких концентрациях соли и отрицательных температурах [Glass et al., 2019], 
$a$

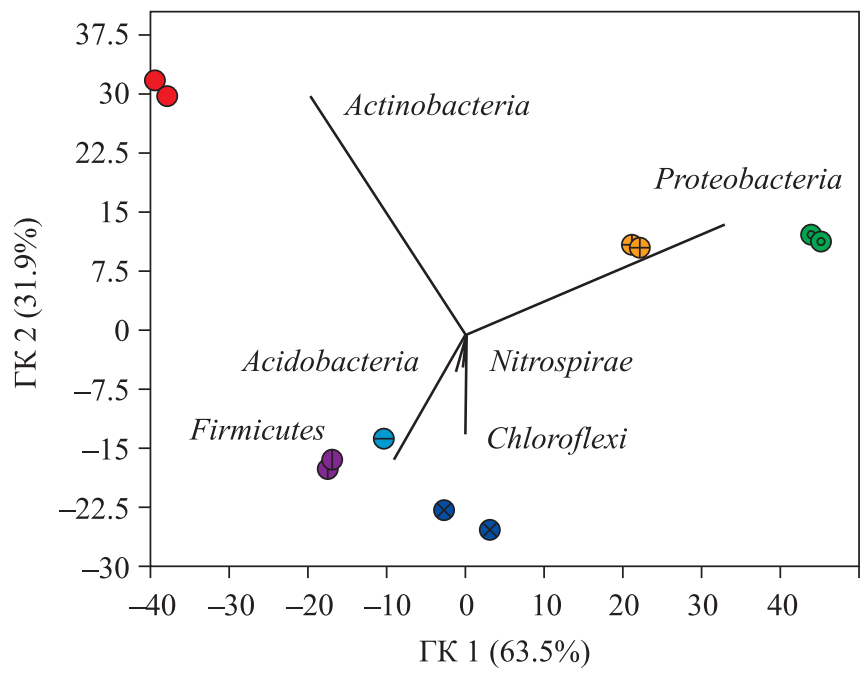

6

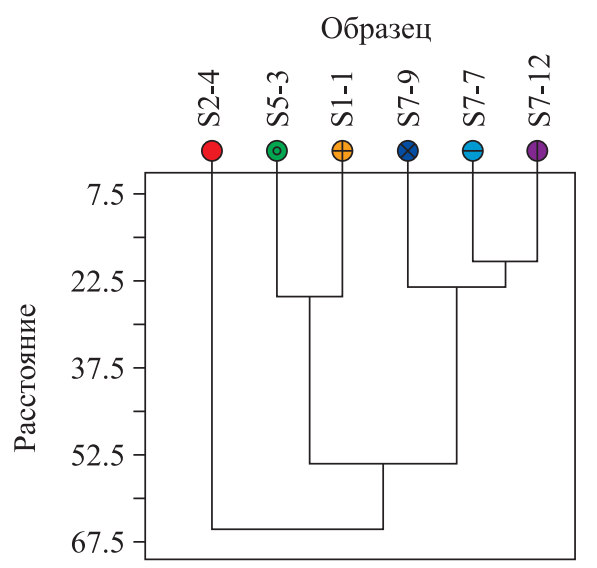

Рис. 7. Результаты анализа методом главных компонент относительного обилия филумов домена Васteria для двух технических повторностей ( $a$ ) и дендрограмма кластерного анализа (б)

a. Показаны преобладающие таксономические факторы, которые в основном ответственны за расхождение между выборками.

б. В качестве индекса сходства для кластерного анализа использовано евклидово расстояние

а также часто встречаются в подводных анаэробных экосистемах с низким содержанием органических веществ [Orsi, 2018].

\section{ЗАКЛЮЧЕНИЕ}

Впервые для о. Западный Шпицберген было проведено исследование бактериального разнообразия образцов вечной мерзлоты из отложений морских террас возрастом от позднего плейстоцена до голоцена. Использовались взаимодополняющие методы - профилирование V4 региона гена $16 \mathrm{~S}$ рРНК, определение общей численности прокариотных клеток и аэробное культивирование психротолерантной части бактериального сообщества. Общее количество клеток в образцах вечной мерзлоты составило около $10^{7}$ клеток в 1 г мерзлоты, что на два порядка меньше, чем в современных морских отложениях, и на один-два порядка больше, чем в ранее изученных приповерхностных слоях вечной мерзлоты. Количество культивируемых аэробных бактерий в вечной мерзлоте Западного Шпицбергена составило $10^{4} \mathrm{KOE} \mathrm{в} 1$ г мерзлоты, что на полтора-три порядка ниже, чем в ранее исследованных образцах более низкотемпературной мерзлоты Арктики.

Уменьшение числа (КОЕ/г) и разнообразия бактериальных сообществ в вечной мерзлоте с близкими к нулю отрицательными температурами показывает, насколько чувствительны древние микробные сообщества к потеплению климата.

Сообщества, характеризуемые преобладанием бактериальных филумов Actinobacteria, Proteobacteria, Chloroflexi, Nitrospirae и Firmicutes, оказались схожими с составом сообществ современных прибрежных и морских рыхлых осадочных пород. Предположительно, они формировались в основном в анаэробных, а также в смешанных аэробно-анаэробных условиях и были активными как до замерзания, так и в условиях «теплой» мерзлоты.

Функциональная роль обнаруженных бактериальных сообществ, по-видимому, сводилась к следующим процессам: гетеротрофной психрофильной активности (во всех исследованных образцах), анаэробному окислению метана бактериями рода Methylobacter (в образце устья р. Грен - обр. S1-1) и сульфатредуцирующей активности бактерий филумов Firmicutes и Nitrospirae (в образцах из четвертой морской террасы южного берега Исфьорда - обр. S2-4 и первой морской террасы на м. Финнесет - образцы S7-7 и S7-9). Во всех образцах также предположено наличие микробиологических процессов преобразования углеводородов, вымываемых из угленосных скальных грунтов.

Изоляты аэробных бактерий родов Arthrobacter, Pseudarthrobacter, Psychrobacter и Rhodoferax составили менее $1 \%$ общего бактериального разнообразия образцов. До замерзания эти виды, вероятно, могли выполнять в холодных экосистемах Шпицбергена функции преобразования органического вещества, такого как протеины и хитин.

Изотопный состав метана и углекислого газа в скв. 7 позволяет предположить, что эти отложения могли образоваться в условиях поступления газов из третичных скальных пород.

\section{ФИНАНСИРОВАНИЕ}

Работа выполнена при поддержке Российского научного фонда по проекту № 19-77-10066 (Н.Э. Демидов) и Немецкого научно-исследовательского общества (DFG) по проекту № WE4390/7-1 (C. Веттерих). Полевые работы на криосферном полигоне под Баренцбургом проводились в рамках Российской арктической экспедиции на арх. Шпицберген (РАЭШ). 


\section{БЛАГОДАРНОСТИ}

Авторы благодарят Е.А. Воробьеву (Московский государственный университет им. М.В. Ломоносова) за помощь в организации экспериментальных работ по культивированию аэробных бактерий из образцов вечной мерзлоты; А.Ю. Меркеля (Институт микробиологии им. С.Н. Виноградского РАН) - за проведение NGSанализа и консультации по методу; М.Ю. Чербунину и Д.Г. Шмелева - за консультацию о свойствах метана в вечной мерзлоте.

\section{КОНФЛИКТ ИНТЕРЕСОВ}

Авторы заявляют об отсутствии конфликта интересов.

\section{ЛИТЕРАТУРА}

Алексеев И.И., Абакумов Е.В. Таксономическое и морфологическое разнообразие почв окрестностей залива Гренфьорд (архипелаг Шпицберген) // Самарская Лука: Проблемы региональной и глобальной экологии. 2016. T. 25, № 4. С. 256-161.

Демидов Н.Э., Баранская А.В., Дурденко Е.В., Занина О.Г., Караевская Е.С., Пушина З.В., Ривкина Е.М., Спирина E.B., Спенсер Р. Биогеохимия мерзлых толщ арктического побережья полуострова Гыдан // Проблемы Арктики и Антарктики. 2016а. Т. 1, № 3 (109). С. 34- 49.

Демидов Н.Э., Караевская Е.С., Веркулич С.Р., Никулина А.Л., Саватюгин Л.М. Первые результаты мерзлотных наблюдений на криосферном полигоне Российского научного центра на архипелаге Шпицберген (РНЦШ) // Проблемы Арктики и Антарктики. $2016 б$. T. 1, № 4 (110). С. 67-79.

Демидов Н.Э., Борисик А.Л., Веркулич С.Р., Веттерих С., Гунар А.Ю., Демидов В.Э., Желтенкова Н.В., Кошурников А.В., Милославский М.Ю., Никулина А.Л., Новиков А.Л., Саватюгин Л.М., Сироткин А.Н., Терехов А.В., Угрюмов Ю.В., Шарин В.В., Ширрмейстер Л. Мерзлотно-гидрогеологические условия острова Западный Шпицберген в районе российских рудников и поселков Баренцбург, Колсбей, Грумант: Новые данные и обобщение работ начиная с 1930 -х годов // Геофизические процессы и биосфера. 2020. Т. 19, № 4. С. 68-93. https://doi.org/10.21455/GPB2020.4-6

Караевская Е.С., Демидов Н.Э., Шмелев Д.Г., Ривкина E.M., Булат С.А. Изучение бактериальных сообществ многолетнемерзлых пород оазисов Антарктиды методами культивирования // Проблемы Арктики и Антарктики. 2017. Т. 1, № 2 (112). С. 27-42.

Меркель А.Ю., Тарновецкий И.Ю., Подосокорская О.А., Тощаков C.B. Анализ систем праймеров на ген $16 \mathrm{~S}$ рРНК для профилирования термофильных микробных сообществ // Микробиология. 2019. Т. 88, № 6. С. 655-664.

Мэгарран Э. Экологическое разнообразие и его измерение. М.: Мир, 1992. 184 с.

Соловьева Д.А., Савельева Л.А., Веркулич С.Р., Зазовская Э.П. Послеледниковые изменения природной среды в районе поселка Баренцбург (остров Западный Шпицберген) // Theory and methods of Polar science: Proc. of Intern. youth sci. conf. on the polar geodesy, glaciology, hydrology and geophysics. St. Petersburg, 2018. Р. 213-222. (На рус. яз.).

Тараник A.A. Геохимические показатели участков долговременной добычи угольного метана как самостоятельного источника энергии на примере месторождений Донбасса // Газовая промышленность. 2017. Т. 755, № 7. С. 24-27.
Хлебникова Г.М., Гиличинский Д.А., Федоров-Давыдов Д.Г., Воробьева Е.А. Количественная оценка микроорганизмов в многолетнемерзлых отложениях и погребенных почвах // Микробиология. 1990. Т. 59, № 1. C. $148-155$.

Чернов Р.А., Муравьев А.Я. Современные изменения площади ледников западной части Земли Норденшельда (архипелаг Шпицберген) // Лёд и Снег. 2018. Т 58 (4). C. $462-472$.

Шакиров Р.Б. Особенности химического и изотопного состава углеводородных газов вулканов Менделеева и Головнина (о. Кунашир) // Геохимия. 2014. № 3. C. 267-267.

Юдович Ю.Е., Кетрис М.П. Соотношения изотопов углерода в стратисфере и биосфере // Биосфера. 2010. Т. 2, № 2. C. 231-247.

Aissa F.B., Postec A., Erauso G., Payri C., Pelletier B., Hamdi M., Bernard Ollivier, Fardeau M.L. Vallitalea pronyensis $s p$. nov., isolated from a marine alkaline hydrothermal chimney // Inter. J. Systematic and Evolutionary Microbiology. 2014. V. 64 (4). P. 1160-1165.

Albuquerque L., França L., Rainey F.A., Schumann P., Nobre M.F., da Costa M.S. Gaiella occulta gen. nov, $s p$. nov., a novel representative of a deep branching phylogenetic lineage within the class Actinobacteria and proposal of Gaiellaceae fam. nov. andGaiellales ord. nov // Systematic and Applied Microbiology. 2011. V. 34 (8). P. 595-599.

Alcántara-Hernández R.J., Centeno C.M., Ponce-Mendoza A., Batista S., Merino-Ibarra M., Campo J., Falcón L.I. Characterization and comparison of potential denitrifiers in microbial mats from King George Island, Maritime Antarctica // Polar Biology. 2014. V. 37 (3). P. 403-416.

Alperin M.J., Reeburgh W.S. Inhibition experiments on anaerobic methane oxidation // Applied and Environmental Microbiology. 1985. V. 50 (4). P. 940-945.

Bajerski F., Wagner D. Bacterial succession in Antarctic soils of two glacier forefields on Larsemann Hills, East Antarctica // FEMS Microbiology Ecology. 2013. V. 85 (1). P. 128-142.

Baltrus D.A., Yourstone S., Lind A., Guilbaud C., Sands D.C., Jones C.D., Morris C.E., Dangl J.L. Draft genome sequences of a phylogenetically diverse suite of Pseudomonas syringae strains from multiple source populations // Genome Announcements. 2014. V. 2 (1). P. 1-2. URL: https://mra.asm.org/content/ga/2/1/e0119513.full.pdf

Bolyen E., RideoutJ.R., Dillon M.R., Bokulich N.A., C.C.Abnet, Al-Ghalith G.A., Alexander H., Alm E.J., Arumugam M., Asnicar F., Bai Y., Bisanz J.E., Bittinger K., Brejnrod A., Brislawn C.J., Brown C.T., Callahan B.J., CaraballoRodríguez M.A., Chase J., Cope E.K., DaSilva R., Diener C., Dorrestein P.C., Douglas G.M., Durall D.M., Duvallet C., Edwardson C.F., Ernst M., Estaki M., Fouquier J., Gauglitz J.M., Gibbons S.M., Gibson D.L., Gonzalez A., Gorlick K., Guo J., Hillmann B., Holmes S., Holste H., Huttenhower C., Huttley G.A., Janssen S., Jarmusch A.K., Jiang L., Kaehler B.D., Kang K.B., Keefe K.R., Keim P., Kelley S.T., Knights D., Koester I., Kosciolek T., Kreps J., Langille M.G.I., Lee J., Ley R., Liu Y.-X., Loftfield E., Lozupone C., Maher M., Marotz C., Martin B.D., McDonald D., McIver L.J., Melnik A.V., MetcalfJ.L., Morgan S.C., Morton J.T., Naimey A.T., NavasMolina J.A., Nothias L.F., Orchanian S.B., Pearson T., Peoples S.L., Petras D., Preuss M.L., Pruesse E., Rasmussen L.B., Rivers A., Robeson M.S. II, Rosenthal P., Segata N., Shaffer M., Shiffer A., Sinha R., Song S.J., 
Spear J.R., Swafford A.D., Thompson L.R., Torres P.J., Trinh P., Tripathi A., Turnbaugh P.J., Ul-HasanS., van der Hooft J.J.J., Vargas F., Vázquez-Baeza Y., Vogtmann E., von Hippel M., Walters W., Wan Y., Wang M., Warren J., Weber K.C., Williamson C.H.D., Willis A.D., Xu Z.Z., Zaneveld J.R., Zhang Y., Zhu Q., Knight R., Caporaso J.G. Reproducible, interactive, scalable and extensible microbiome data science using QIIME 2 // Nat. Biotechnol. 2019. V. 37 (8). P. 852-857. Erratum in: Nat. Biotechnol. 2019. V. 37 (9). P. 1091.

Bowman J.P., McCuaig R.D. Biodiversity, community structural shifts, and biogeography of prokaryotes within Antarctic continental shelf sediment //Applied and Environmental Microbiology. 2003. V. 69 (5). P. 2463-2483.

Bueno de Mesquita C.P.B., Schmidt S.K., Suding K.N. Litterdriven feedbacks influence plant colonization of a high elevation early successional ecosystem // Plant and Soil. 2019. V. 444 (1). P. 71-85.

Cabrera-Ospino M.C. Phylogeny and diversity of genes for poorly characterized type of arsenite oxidase involved in anaerobic arsenic oxidation: Pd.D. Thesis. 2018. (На яп. яз.).

Carr S.A., Orcutt B.N., Mandernack K.W., Spear J.R. Abundant Atribacteria in deep marine sediment from the Adélie Basin, Antarctica // Frontiers in Microbiology. 2015. V. 6. P. 872.

Chao A. Nonparametric estimation of the number of classes in a population // Scand. J. Statistics. 1984. V. 11. P. 265-270.

Chen M.-Y., Wu Sh.-H., Lin G.-H., Lu Ch.-P., Lin Y.-T., Chang W.-Ch., Tsay S.-S. Rubrobacter taiwanensis sp.nov., a novel thermophilic, radiation-resistant species isolated from hot springs // Inter. J. Systematic and Evolutionary Microbiology. 2004. T. 54. № 5. P. 1849-1855.

Coolen M.J., Orsi W.D. The transcriptional response of microbial communities in thawing Alaskan permafrost soils // Frontiers in Microbiology. 2015. V. 6. P. 197.

Coolen M.J., Talbot H.M., Abbas B.A., Ward C., Schouten S., Volkman J.K., Damsté J.S. Sources for sedimentary bacteriohopanepolyols as revealed by $16 \mathrm{~S}$ rDNA stratigraphy // Environmental Microbiology. 2008. V. 10 (7). P. 1783-1803.

Costello E.K., Schmidt S.K. Microbial diversity in alpine tundra wet meadow soil: Novel Chloroflexi from a cold, water-saturated environment // Environmental Microbiology. 2006. V. 8 (8). P. 1471-1486.

Cravo-Laureau C., Matheron R., Joulian C., Cayol J.L., Hirschler-Réa A. Desulfatibacillum alkenivorans sp. nov., a novel n-alkene-degrading, sulfate-reducing bacterium, and emended description of the genus Desulfatibacillum // Inter. J. Systematic and Evolutionary Microbiology. 2004. V. 54 (5). P. 1639-1642.

Demidov N., Wetterich S., Verkulich S., Ekaykin A., Meyer H., Anisimov M., Schirrmeister L., Demidov V., Hodson A.J. Geochemical signatures of pingo ice and its origin in Grøndalen, West Spitsbergen // The Cryosphere. 2019. V. 13. P. 3155-3169.

De Wever A., Muylaert K., Van der Gucht K., Pirlot S., Cocquyt C., Descy J.P., Plisnier P.-D., Vyverman W. Bacterial community composition in Lake Tanganyika: Vertical and horizontal heterogeneity // Applied and Environmental Microbiology. 2005. V. 71 (9). P. 5029-5037.

Dojka M.A., Hugenholtz P., Haack S.K., Pace N.R. Microbial diversity in a hydrocarbon and chlorinated-solventcontaminated aquifer undergoing intrinsic bioreme- diation // Applied and Environmental Microbiology. 1998. 64 (10). P. 3869-3877.

Donachie S. P., Hou S., Lee K.S., Riley C.W., Pikina A., Belisle C., Kempe S., Gregory T.S., Bossuyt A., Boerema J., Liu J., Freitas T.A., Malahoff A., Alam M. The Hawaiian Archipelago: A microbial diversity hotspot // Microbial Ecology. 2014. V. 48 (4). P. 509-520.

Drahota P., Mikutta C., Falteisek L., Duchoslav V., Klementová $M$. Biologically induced formation of realgar deposits in soil // Geochimica et Cosmochimica Acta. 2017. V. 218. P. 237-256.

Dziga D., Kokociński M., Barylski J., Nowicki G., Maksylewicz A., Antosiak A., Banaś A.K., Strzałka W. Correlation between specific groups of heterotrophic bacteria and microcystin biodegradation in freshwater bodies of central Europe // FEMS Microbiology Ecology. 2019. V. 95 (11). Fiz. 162.

Elshahed M.S., Youssef N.H., Spain A.M., Sheik C., Najar F.Z., Sukharnikov L.O., Roe B.A., Davis J.P., Schloss P.D., Bailey V.L., Krumholz L.R. Novelty and uniqueness patterns of rare members of the soil biosphere // Applied and Environmental Microbiology. 2008. V. 74 (17). P. 5422-5428.

Fabisch M., Freyer G., Johnson C.A., Büchel G., Akob D.M., Neu T.R., Küsel K. Dominance of 'Gallionella capsiferriformans' and heavy metal association with Gallionella like stalks in metal-rich pH 6 mine water discharge // Geobiology. 2016. V. 14 (1). P. 68-90.

Fadrosh D.W., Ma B., Gajer P., Sengamalay N., Ott S., Brotman R.M., Ravel J. An improved dual-indexing approach for multiplexed 16S rRNA gene sequencing on the Illumina MiSeq platform // Microbiome. 2014. V. 2 (1) P. 6.

Farrow J.A.E., Lawson P.A., Hippe H., Gauglitz U., Collins M.D. Phylogenetic evidence that the Gram-negative nonsporulating bacterium Tissierella (Bacteroides) praeacuta is a member of the Clostridium subphylum of the gram-positive bacteria and description of Tissierella creatinini sp. nov. // Systematic and Evolutionary Microbiology. 1995. V. 45. P. 436-440.

Fendrich C. Halovibrio variabilis gen. nov. sp. nov, Pseudomonas halophila sp. nov. and a new halophilic aerobic coccoid Eubacterium from Great Salt Lake, Utah, USA // Systematic and Applied Microbiology. 1988. V. 11 (1). P. 36-43.

Flynn T.M., Sanford R.A., Ryu H., Bethke C.M., Levine A.D., Ashbolt N.J., Santo Domingo J.W. Functional microbial diversity explains groundwater chemistry in a pristine aquifer // BMC Microbiology. 2013. V. 13 (1). P. 1-15.

Forman S.L., Lubinski D.J., Ingolfsson O., Zeeberg J.J., Snyder J.A., Siegert M.J., Matishov G.G. A review of postglacial emergence on Svalbard, Franz Josef Land and Novaya Zemlya, Northern Eurasia // Quarter. Sci. Rev. 2004. V. 23. P. 1391-1434.

Gallego V., Sanchez-Porro C., García M.T., Ventosa A. Massilia aurea $s p$. nov., isolated from drinking water // Inter. J. Systematic and Evolutionary Microbiology. 2006. V. 56 (10). P. 2449-2453.

Ganzert L., Bajerski F., Wagner D. Bacterial community composition and diversity of five different permafrostaffected soils of Northeast Greenland // FEMS Microbiology Ecology. 2014. V. 89 (2). P. 426-441.

Gilichinsky D.A., Wilson G.S., Friedmann E. I., McKay C.P., Sletten R.S., Rivkina E.M., Vishnivetskaya T.A., Erokhina L.G., Ivanushkina N.E., Kochkina G.A., Shcherbakova V.A., Soina V.S., Spirina E.V., Vorobyova E.A., Fyodorov-Davydov D.G., Hallet B., Ozerskaya S.M., Sorokovikov V.A., Laurinavichyus K.S., Shatilovich A.V., 
Chanton I.P., Ostroumov V.E., Tiedje J.M. Microbial populations in Antarctic permafrost: Biodiversity, state, age and implication for astrobiology // Astrobiology. 2007. V. 7 (2). P. 275-311.

Glass J.B., Ranjan P., Kretz C.B., Nunn B.L., Johnson A.M., McManus J., Stewart F.J. Adaptations of Atribacteria to life in methane hydrates: Hot traits for cold life // bioRxiv. 2019. P. 536078.

Gleeson D.F., Williamson C., Grasby S.E., Pappalardo R.T., Spear J.R., Templeton A.S. Low temperature S0 biomineralization at a supraglacial spring system in the Canadian High Arctic // Geobiology. 2011. V. 9 (4). P. 360-375.

Gołębiewski M., Deja-Sikora E., Cichosz M., Tretyn A., Wróbel B. 16S rDNA pyrosequencing analysis of bacterial community in heavy metals polluted soils // Microbial Ecology. 2014. V. 67 (3). P. 635-647.

Good I.J. The population frequencies of species and the estimation of population parameters // Biometrika. 1953. V. 40. P. 237-264.

Gupta R.S., Chander P., George S. Phylogenetic framework and molecular signatures for the class Chloroflexi and its different clades; proposal for division of the class Chloroflexi class. nov. into the suborder Chloroflexineae subord. nov. consisting of the emended family Oscillochloridaceae and the family Chloroflexaceae fam. nov., and the suborder Roseiflexineae subord. nov., containing the family Roseiflexaceae fam. nov. // Antonie van Leeuwenhoek. 2012. V. 103 (1). P. 99-119.

Gustave W., Yuan Z.F., Sekar R., Ren Y.X., Liu J.Y., Zhang J., Chen $Z$. Soil organic matter amount determines the behavior of iron and arsenic in paddy soil with microbial fuel cells // Chemosphere. 2019. V. 237. P. 124459.

Hammer Ø., Harper D.A.T., Ryan P.D. PAST: Paleontological statistics software package for education and data analysis // Palaeontologia Electronica. 2001. V. 4, is. 1, art. 4.9 p.

Hanson B.T. Molecular microbial ecology of sediments and subsurface groundwater at a coal tar-contaminated waste site. N.Y.: Cornell Univ., 2013.

Harms C., Ludwig U., Andreesen J.R. Sarcosine reductase of Tissierella creatinophila: purification and characterization of its components // Archives of Microbiology. 1998. V. 170 (6). P. 442-450.

Hitchman S.P., Darling W.G., Williams G.M. Stable isotope ratios in methane containing gases in the United Kingdom. Brit. Geol. Sur., 1990. 25 p. (Tech. Rep. WE/89/30). URL: http://nora.nerc.ac.uk/id/eprint/502528/1/WE89030.pdf

Hugerth L.W., Wefer H.A., Lundin S., Jakobsson H.E., Lindberg M., Rodin S., Engstrand L., Andersson A.F. DegePrime, a program for degenerate primer design for broad-taxonomic-range PCR in microbial ecology studies // Applied and Environmental Microbiology. 2014. V. 80 (16). P. 5116-5123.

Humlum O., Instanes A., Sollid J.L. Permafrost in Svalbard: A review of research history, climatic background and engineering challenges // Polar Research. 2003. V. 22. P. 191-215.

Inceoglu B., Bettaieb A., Da Silva C.A.T., Lee K.S.S., Haj F.G., Hammock B.D. Endoplasmic reticulum stress in the peripheral nervous system is a significant driver of neuropathic pain // Proc. of the Nat. Acad. of Sci. 2015. V. 112 (29). P. 9082-9087.

Jansson J.K., Taş N. The microbial ecology of permafrost // Nature Reviews Microbiology. 2014. V. 12 (6). P. 414- 425.

Jeon C.O., Park M., Ro H.S., Park W., Madsen E.L. The naphthalene catabolic (nag) genes of Polaromonas naphthalenivorans CJ2: Evolutionary implications for two gene clusters and novel regulatory control // Applied and Environmental Microbiology. 2006. V. 72 (2). P. 1086-1095.

Johnson S.S., Hebsgaard M.B., Christensen T.R., Mastepanov M., Nielsen R., Munch K., Brand T., Gilbert M.T.P., Zuber M.T., Bunce M., Rønn R., Gilichinsky D., Froese D., Willerslev E. Ancient bacteria show evidence of DNA repair // Proc. of the Nat. Acad. of Sci. of the USA. 2007. V. 104. P. 14401-14405.

Jørgensen B.B., Beulig F., Egger M., Petro C., Scholze C., Røy $H$. Organoclastic sulfate reduction in the sulfatemethane transition of marine sediments // Geochim. et Cosmochim. Acta. 2019. V. 254. P. 231-245.

Kaden R., Spröer C., Beyer D., Krolla-Sidenstein P. Rhodoferax saidenbachensis sp. nov., a psychrotolerant, very slowly growing bacterium within the family Comamonadaceae, proposal of appropriate taxonomic position of Albidiferax ferrireducens strain $\mathrm{T} 118^{\mathrm{T}}$ in the genus Rhodoferax and emended description of the genus Rhodoferax // Inter. J. Systematic and Evolutionary Microbiology. 2014. V. 64 (4). P. 1186-1193.

Kaminski M.A., Furmanczyk E.M., Sobczak A., Dziembowski A., Lipinski L. Pseudomonas silesiensis sp. nov. strain $\mathrm{A} 3^{\mathrm{T}}$ isolated from a biological pesticide sewage treatment plant and analysis of the complete genome sequence // Systematic and Applied Microbiology. 2018. V. 41 (1). P. 13-22.

KielakA., Pijl A.S., Van Veen J.A., Kowalchuk G.A. Differences in vegetation composition and plant species identity lead to only minor changes in soil-borne microbial communities in a former arable field // FEMS Microbiology Ecology. 2008. V. 63 (3). P. 372-382.

Kim D.U., Kim S.G., Lee H., Park A.Y., Ka J.O. Oryzihumus soli sp. nov., isolated from soil and emended description of the genus Oryzihumus // Inter. J. Systematic and Evolutionary Microbiology. 2017. V. 67 (10). P. 3960 3964.

Konieczna I., Wojtasik B., Kwinkowski M., Burska D., Nowiński K., Żarnowiec P., Kaca W. Analysis of cultivable aerobic bacteria isolated from bottom sediments in the Wijdefjorden region, Spitsbergen // Polish Polar Research. 2011. V. 32 (2). P. 181-195.

Korehi H., Blöthe M., Schippers A. Microbial diversity at the moderate acidic stage in three different sulfidic mine tailings dumps generating acid mine drainage // Research in Microbiology. 2014. V. 165 (9). P. 713-718.

Kuever J., Rainey F.A., Widdel F. Desulfovibrio // Bergeys manual of systematics of archaea and bacteria. N.Y.: John Wiley \& Sons, Inc., 2015. P. 1-17.

Kumar S., Stecher G., Tamura K. MEGA7: Molecular evolutionary genetics analysis version 7.0 for bigger datasets // Molecular Biology and Evolution. 2016. V. 33, is. 7. P. $1870-1874$.

Kumar S., Stecher G., Knyaz C., Tamura K. MEGA X: Molecular evolutionary genetics analysis across computing platforms // Molecular Biol. and Evol. 2018. V. 35. P. $1547-1549$.

Kwon M., Kim M., Priscu J.C., Hong S.G., Kim S.J., Kim O.S. Bacterial biodiversity in permanently ice-covered lakes of the McMurdo Dry Valleys, Antarctica // 15th Intern. simpos. of microbiol. ecology, Seoul, 24-29 August, 2014: Poster. Seoul, 2014.

Lane D.J. 16S/23S rRNA sequencing // Nucleic acid techniques in bacterial systematics / Eds E. Stackebrandt, M. Goodfellow. Chichester, UK: John Wiley \& Sons Ltd, 1991. P. 115- 175. 
Lee Y.J., Romanek C.S., Wiegel J. Desulfosporosinus youngiae $s p$. nov., a spore-forming, sulfate-reducing bacterium isolated from a constructed wetland treating acid mine drainage // Inter. J. Systematic and Evolutionary Microbiology. 2009. V. 59 (11). P. 2743-2746.

Mangerud J. Radiocarbon dating of marine shells, including a discussion of apparent age of recent shells from Norway // Boreas. 1972. V. 1 (2). P. 143-172.

Miller C.B., Wheeler P.A. Biological oceanography. 2nd ed. N.Y.: John Wiley \& Sons, 2012. 498 p.

Mitzscherling J., Winkel M., Winterfeld M., Horn F., Yang S., Grigoriev M.N., Wagner D., Overduin P.P., Liebner S. The development of permafrost bacterial communities under submarine conditions // J. Geophys. Res. Biogeosci. 2017. V. 122 (7). P. 1689-1704.

Mitzscherling J., Horn F., Winterfeld M., Mahler L., Kallmeyer J., Overduin P.P., Schirrmeister L., Winkel M., Grigoriev M.N., Wagner D., Liebner S. Microbial community composition and abundance after millennia of submarine permafrost warming // Biogeosci. 2019. V. 16. P. 3941-3958.

Mollenhauer G., Grotheer H., Gentz T., Bonk E., Hefter J. Standard operation procedures and performance of the MICADAS radiocarbon laboratory at Alfred Wegener Institute (AWI), Germany Nuclea // Instruments and Methods in Physics Res. Sect. B: Beam Interactions with Materials and Atoms. 2021. V. 496. P. 45-51.

Müller A.L., De Rezende J.R., Hubert C.R., Kjeldsen K.U., Lagkouvardos I., Berry D., Jørgensen B.B., Loy A. Endospores of thermophilic bacteria as tracers of microbial dispersal by ocean currents // The ISME J. 2014. V. 8 (6). P. $1153-1165$.

Müller O., Bang-Andreasen T., White III R.A., Elberling B., Taş N., Kneafsey T., Jansson J.K., Øvreås L. Disentangling the complexity of permafrost soil by using high resolution profiling of microbial community composition, key functions and respiration rates // Environmental Microbiology. 2018. V. 20 (12). P. 4328-4342.

Niu J., Deng J., Xiao Y., He Z., Zhang X., Van Nostrand J.D., Liang Y., Deng Y., Liu X., Yin H. The shift of microbial communities and their roles in sulfur and iron cycling in a copper ore bioleaching system // Sci. Rep. 2016. V. 6. P. 34744 .

Nunoura T., Hirai M., Miyazaki M., Kazama H., Makita H., Hirayama H., Furushima Y., Yamamoto H., Imachi H., Takai $K$. Isolation and characterization of a thermophilic, obligately anaerobic and heterotrophic marine Chloroflexi bacterium from a Chloroflexi-dominated microbial community associated with a Japanese shallow hydrothermal system, and proposal for Thermomarinilinea lacunofontalis gen. nov., sp. nov. // Microbes and Environments. 2013. V. 28 (2). P. 228-235.

Opel T., Murton J.B., Wetterich S., Meyer H., Ashastina K., Günther F., Grotheer H., Mollenhauer G., Danilov P.P., Boeskorov V., Savvinov G.N., Schirrmeister L. Past climate and continentality inferred from ice wedges at Batagay megaslump in the Northern Hemisphere's most continental region, Yana Highlands, interior Yakutia // Climate of the Past. 2019. V 15. P. 1443-1461.

Orsi W.D. Ecology and evolution of seafloor and subseafloor microbial communities // Nature Rev. Microbiology. 2018. V. 16 (11). P. 671-683.

Pascual J., Blanco S., García-López M., García-Salamanca A., Bursakov S.A., Genilloud O., Bills J.F., Ramos J.L., van Dillewijn $P$. Assessing bacterial diversity in the rhizosphere of Thymus zygis growing in the Sierra Nevada National Park (Spain) through culture-dependent and independent approaches // PLoS One. 2016. V. 11 (1). P. e0146558.
Pavlov M.S., Lira F., Martinez J.L., Olivares-Pacheco J., Marshall S.H. Pseudomonas fildesensis sp. nov., a psychrotolerant bacterium isolated from Antarctic soil of King George Island, South Shetland Islands // Inter. J. Systematic and Evolutionary Microbiology. 2020. P. ijsem004165.

Peipoch M., Jones R., Valett H.M. Spatial patterns in biofilm diversity across hierarchical levels of river-floodplain landscapes // PLOS One. 2015. V. 10 (12). P. e0144303.

Perini L., Gostinčar C., Gunde-Cimerman N. Fungal and bacterial diversity of Svalbard subglacial ice // Sci. Rep. 2019. V. 9 (1). P. 1-15.

Pozzato L., Cathalot C., Berrached C., Toussaint F., Stetten E., Caprais J.C., Pastor L., Olu K., Rabouille C. Early diagenesis in the Congo deep-sea fan sediments dominated by massive terrigenous deposits: Pt. I. Oxygen consumption and organic carbon mineralization using a micro-electrode approach // Deep Sea Res. Pt. II. Topical studies in oceanography. 2017. V. 142. P. 125-138.

Quéméneur M., Erauso G., Frouin E., Zeghal E., Vandecasteele C., Ollivier B., Tamburini Ch., Garel M., Menez B., Postec A. Hydrostatic pressure helps to cultivate an original anaerobic bacterium from the Atlantis Massif subseafloor (IODP Expedition 357): Petrocella atlantisensis gen. nov. sp. nov. // Frontiers in Microbiology. 2019. V. 10. P. 1497.

Ravenschlag K., Sahm K., Amann R. Quantitative molecular analysis of the microbial community in marine Arctic sediments (Svalbard) // Applied and Environmental Microbiology. 2001. V. 67 (1). P. 387-395.

Reddy P.V.V., Rao S.S.S.N., Pratibha M.S., Sailaja B., Kavya B., Manorama R.R., Shivaji S. Bacterial diversity and bioprospecting for cold-active enzymes from cultuvable bacteria associated with sediment from a melt water stream of Midtre Lovénbreen glacier, an Arctic glacier // Res. in Microbiology. 2009. V. 160 (8). P. 538-546.

Reimer P.J., Bard E., Bayliss A., Beck J.W., Blackwell P.G., Bronk Ramsey C., Buck C.E., Cheng H., Edwards R.L., Friedrich M., Grootes P.M., Guilderson T.P., Haflidason H., Hajdas I., Hatté C., Heaton T.J., Hogg A.G., Hughen K.A., Kaiser K.F., Kromer B., Manning S.W., Niu M., Reimer R.W., Richards D.A., Scott E.M., Southon J.R., Turney C.S.M., van der Plicht J. IntCal13 and MARINE13 radiocarbon age calibration curves $0-50000$ years cal BP // Radiocarbon. 2013. V. 55 (4). P. 1869-1887.

Romaniuk K., Ciok A., Decewicz P., Uhrynowski W., Budzik K., Nieckarz M., Dziewit L. Insight into heavy metal resistome of soil psychrotolerant bacteria originating from King George Island (Antarctica) // Polar Biology. 2018. V. 41 (7) P. 1319-1333.

Sahm K., Berninger U.G. Abundance, vertical distribution, and community structure of benthic prokaryotes from permanently cold marine sediments (Svalbard, Arctic Ocean) // Marine Ecology Progress Ser. 1998. V. 165. P. 71-80.

Salvigsen O., Høgvard K. Glacial history, Holocene shoreline displacement and palaeoclimate based on radiocarbon ages in the area of Bockfjorden, North-Western Spitsbergen, Svalbard // Polar Res. 2005. V. 25 (1). P. 15-24.

Sánchez-Andrea I., Stams A.J., Amils R., Sanz J.L. Enrichment and isolation of acidophilic sulfate-reducing bacteria from Tinto River sediments // Environ. Microbiol. Rep. 2013. V. 5 (5). P. 672-678.

Schimel J., Balser T.C., Wallenstein M. Microbial stressresponse physiology and its implications for ecosystem function // Ecology. 2007. V. 88 (6). P. 1386-1394.

Senger K., Brugmans P., Grundvåg S.-A., Jochmann M., Nøttvedt A., Olaussen S., Skotte A., Smyrak-Sikora A. 
Petroleum, coal and research drilling onshore Svalbard: A historical perspective // Norwegian J. Geol. 2019. V. 99 (3).

Singh S.K., Verma P., Ramaiah N., Chandrashekar A.A., Shouche Y.S. Phylogenetic diversity of archaeal 16S rRNA and ammonia monooxygenase genes from tropical estuarine sediments on the central west coast of India // Res. in Microbiology. 2010. V. 161(3). P. 177-186.

Singh P., Singh S.M., Singh R.N., Naik S., Roy U., Srivastava A., Bölter $M$. Bacterial communities in ancient permafrost profiles of Svalbard, Arctic // J. Basic Microbiology. 2017. V. 57 (12). P. 1018-1036.

Srinivas T.N.R., Rao S.N., Reddy P.V.V., Pratibha M.S., Sailaja B., Kavya B., Shivaji S. Bacterial diversity and bioprospecting for cold-active lipases, amylases and proteases, from bacteria of Kongsfjorden and Ny-Ålesund, Svalbard, Arctic // Current Microbiology. 2009. V. 59 (5). P. 537-547.

Steven B., Briggs G., McKay Ch.P., Pollard W.H., Greer C.W., Whyte L.G. Characterization of the microbial diversity in permafrost sample from the Canadian high Arctic using culture-dependent and culture-independent methods // FEMS Microbiology Ecology. 2007. P.513-523.

Steven B., Pollard W.H., Greer C.W., Whyte L.G. Microbial diversity and activity through a permafrost/ground ice core profile from the Canadian high Arctic // Environmental Microbiology. 2008. V. 10 (12). P. 3388-3403.

Svendsen J.I., Mangerud J. Holocene glacial and climatic variations on Spitsbergen, Svalbard // The Holocene. 1997. V. 7 (1). P. 45-57.

Szpak M.T., Monteys X., O’Reilly S., Simpson A.J., Garcia X., Evans R.L., Allen C.C.R., McNally D.J., CountierMurias D., Kelleher B.P. Geophysical and geochemical survey of a large marine pockmark on the Malin Shelf, Ireland // Geochemistry, Geophysics, Geosystems. 2012. V. 13 (1). 18 p.

Tamura K., Nei M. Estimation of the number of nucleotide substitutions in the control region of mitochondrial DNA in humans and chimpanzees // Molecular Biology and Evolution. 1993. V. 10. P. 512-526.

Taş N., Prestat E., Wang S., Wu Y., Ulrich C., Kneafsey T., Tringe S.G., Torn M.S., Hubbard S.S., Jansson J.K. Landscape topography structures the soil microbiome in arctic polygonal tundra // Nature Communications. 2018. V. 9 (1). P. 1-13.

Teske A., Durbin A., Ziervogel K., Cox C., Arnosti C. Microbial community composition and function in permanently cold seawater and sediments from an Arctic fjord of Svalbard // Applied and Environmental Microbiology. 2011. V. 77 (6). P. 2008-2018.

Tischer K., Kleinsteuber S., Schleinitz K.M., Fetzer I., Spott O., Stange F., Lohse U., Franz J., Neumann F., Gerling S., Schmind Ch., Hasselwander E., Harms H., Wendeberg A. Microbial communities along biogeochemical gradients in a hydrocarbon-contaminated aquifer // Environmental Microbiology. 2013. V. 15 (9). P. 2603-2615.

Tuorto S.J., Darias P., Mc Guinness L.R., Panikov N., Zhang T., Häggblom M.M., Kerkhof L.J. Bacterial genome replication at subzero temperatures in permafrost // The ISME J. 2014. V. 8 (1). P.139-149.

Vázquez S., Monien P., Minetti R.P., Jürgens J., Curtosi A., Primitz J.V., Frikenhaus S., Abele D., Mac Comack W., Helmke E. Bacterial communities and chemical parameters in soils and coastal sediments in response to diesel spills at Carlini Station, Antarctica // Sci. of the Total Environment. 2017. V. 605. P. 26-37.

Vishnivetskaya T., Kathariou S., McGrath J., Gilichinsky D., Tiedje J.M. Low-temperature recovery strategies for the isolation of bacteria from ancient permafrost sediments // Extremophiles. 2000. V. 4 (3). P. 165-173.

Wang F., Gai Y., Chen M., Xiao X. Arthrobacter psychrochitiniphilus sp. nov., a psychrotrophic bacterium isolated from Antarctica // Inter. J. Systematic and Evolutionary Microbiology. 2009. V. 59. P. 2759-2762.

Wartiainen I., Hestnes A.G., McDonald I.R., Svenning M.M. Methylobacter tundripaludum sp. nov., a methane-oxidizing bacterium from Arctic wetland soil on the Svalbard islands, Norway $(78$ N) // Inter. J. Systematic and Evolutionary Microbiology. 2006. V. 56, (1). P. 109-113.

Watanabe T., Kojima H., Fukui M. Identity of major sulfurcycle prokaryotes in freshwater lake ecosystems revealed by a comprehensive phylogenetic study of the dissimilatory adenylylsulfate reductase // Sci. Rep. 2016. V. 6. P. 36262.

Weber Y., Damsté J.S.S., Zopfi J., De Jonge C., Gilli A., Schubert C.J., Lepori F., Lehmann M.F., Niemann H. Redox-dependent niche differentiation provides evidence for multiple bacterial sources of glycerol tetraether lipids in lakes // Proc. of the Nat. Acad. of Sci. 2018. V. 115 (43). P. 10926-10931.

Wei N., Finneran K.T. Microbial community analyses of three distinct, liquid cultures that degrade methyl tert-butyl ether using anaerobic metabolism // Biodegradation. 2009. V. 20 (5). P. 695.

Wegner C.E., Liesack $W$. Unexpected dominance of elusive Acidobacteria in early industrial soft coal slags // Front. in Microbiol. 2017. V. 8. P. 1023.

Wilhelm R.C., Hanson B.T., Chandra S., Madsen E. Community dynamics and functional characteristics of naphthalene-degrading populations in contaminated surface sediments and hypoxic/anoxic groundwater // Environmental Microbiology. 2018. V. 20 (10). P. 3543-3559.

Yamada T., Imachi H., Ohashi A., Harada H., Hanada S., Kamagata Y., Sekiguchi Y. Bellilinea caldifistulae gen. nov., sp. nov. and Longilinea arvoryzae gen. nov., sp. nov., strictly anaerobic, filamentous bacteria of the phylum Chloroflexi isolated from methanogenic propionatedegrading consortia // Inter. J. Systematic and Evolutionary Microbiology. 2007. V. 57 (10). P. 2299-2306.

Zeglin L.H., Wang B., Waythomas C., Rainey F., Talbot S.L. Organic matter quantity and source affects microbial community structure and function following volcanic eruption on Kasatochi Island, Alaska // Environ. Microbiol. 2016. V. 18 (1). P. 146-158.

Zeng Y., Kobližek M. Phototrophic Gemmatimonadetes: A new «purple» branch on the bacterial tree of life // Modern topics in the phototrophic prokaryotes. Cham: Springer, 2017. P. 163-192.

Zeng Y., Selyanin V., Lukě̌ M., Dean J., Kaftan D., Feng F., Kobližek $M$. Characterization of the microaerophilic, bacteriochlorophyll a-containing bacterium Gemmatimonas phototrophica sp. nov, and emended descriptions of the genus Gemmatimonas and Gemmatimonas aurantiaca // Inter. J. Systematic and Evolutionary Microbiology. 2015. V. 65 (8). P. 2410-2419.

Zeng Y.-X.,Yu Y., Liu Y., Li H.-R. Psychrobacter glaciei sp. nov., isolated from the ice core of an Arctic glacier // Inter. J. Systematic and Evolutionary Microbiology. 2016. V. 66. P. 1792-1798.

Zhang D.C., Schumann P., Liu H.C., Xin Y.H., Zhou Y.G., Schinner F., Margesin R. Arthrobacter alpinus sp. nov., a psychrophilic bacterium isolated from alpine soil // Inter. J. Systematic and Evolutionary Microbiology. 2010. V. 60 (9). P. 2149-2153. 
Сведения об авторах

КАРАЕВСКАЯ Екатерина Сергеевна - ГНЦ РФ «Арктический и антарктический научноисследовательский институт». Россия, 199397, г. Санкт-Петербург, ул. Беринга, д. 38; Институт общей генетики им. Н.И. Вавилова РАН. Россия, 119991, г. Москва, ул. Губкина, д. 3. E-mail: katya_k_s@mail.ru

ДЕМИДОВ Никита Эдуардович - ГНЦ РФ «Арктический и антарктический научноисследовательский институт». Россия, 199397, г. Санкт-Петербург, ул. Беринга, д. 38. E-mail: nikdemidov@mail.ru

КАЗАНЦЕВ Владимир Сергеевич - Институт физики атмосферы имени А.М. Обухова РАН. Россия, 119017, г. Москва, Пыжевский пер., д. 3. E-mail: kazantsev@ifaran.ru

ЕЛИЗАРОВ Иван Михайлович - Федеральный исследовательский центр «Фундаментальные основы биотехнологии» РАН, Институт микробиологии имени С.Н. Виноградского РАН. Россия, 117312, г. Москва, просп. 60 лет Октября, д. 2, корп. 2. E-mail: ivan.elizarov@gmail.com

КАЛОШИН Александр Григорьевич - Научно-аналитический центр, Апрелевское отделение Всероссийского научно-исследовательского геологического нефтяного института. Россия, 143360 , Московская обл., г. Апрелевка, ул. 1-я Кетрица, д. 1.

ПЕТРОВ Александр Леонидович - Научно-аналитический центр, Апрелевское отделение Всероссийского научно-исследовательского геологического нефтяного института. Россия, 143360, Московская обл., г. Апрелевка, ул. 1-я Кетрица, д. 1. E-mail: a.petrov@vnigni.ru

КАРЛОВ Денис Сергеевич - Всероссийский научно-исследовательский институт сельскохозяйственной микробиологии. Россия, 196608, г. Санкт-Петербург; г. Пушкин, шоссе Подбельского, д. 3. E-mail: deniskarlov23@gmail.com

ШИРРМАЙСТЕР Лутц - Институт Альфреда Вегенера Центра полярных и морских исследований имени Гельмгольца, отдел исследований вечной мерзлоты. Германия, 14473, г. Потсдам, Телеграфенберг A45. E-mail: Lutz.Schirrmeister@awi.de

БЕЛОВ Андрей Антонович - Московский государственный университет имени М.В. Ломоносова, факультет почвоведения. Россия, 119991, г. Москва, Ленинские горы, д. 1. E-mail: and.ant.be@gmail.com ВЕТТЕРИХ Себастьян - Институт Альфреда Вегенера Центра полярных и морских исследований имени Гельмгольца, отдел исследований вечной мерзлоты. Германия, 14473, г. Потсдам, Телеграфенберг A45. E-mail: sebastian.wetterich@awi.de

\title{
BACTERIAL COMMUNITIES OF FROZEN QUATERNARY SEDIMENTS OF MARINE ORIGIN ON THE COAST OF WESTERN SPITSBERGEN
}

\section{(C) 2021 E.S. Karaevskaya ${ }^{1,2}$ *, N.E. Demidov ${ }^{1}$, V.S. Kazantsev ${ }^{3}$, I.M. Elizarov ${ }^{4}$, A.G. Khaloshin ${ }^{5}$, A.L. Petrov ${ }^{5}$, D.S. Karlov ${ }^{6}$, L. Schirmeister ${ }^{7}$, A.A. Belov ${ }^{8}$, S. Wetterich ${ }^{7}$}

${ }^{1}$ State Scientific Centre of the Russian Federation «Arctic and Antarctic Research Institute», St. Petersburg, Russia

${ }^{2}$ Vavilov Institute of General Genetics, Russian Academy of Sciences, Moscow, Russia

${ }^{3}$ Obukhov Institute of Atmospheric Physics, Russian Academy of Sciences, Moscow, Russia

${ }^{4}$ Federal Research Centre «Fundamentals of Biotechnology» of the Russian Academy of Sciences,

Vinogradsky Institute of Microbiology, Russian Academy of Sciences, Moscow, Russia

${ }^{5}$ Scientific-Analitical Centre, Aprelevka Branch of the All-Russian Research Geological Oil Institute, Moscow region, Aprelevka, Russia

${ }^{6}$ All-Russian Research Institute for Agricultural Microbiology, St. Petersburg; Pushkin, Russia

${ }^{7}$ Alfred Wegener Institute, Helmholtz Center for Polar and Marine Research,

Department of Permafrost Research, Potsdam, Germany

${ }^{8}$ Lomonosov Moscow State University, Faculty of Soil Science, Moscow, Russia

*e-mail: katya_k_s@mail.ru

\begin{abstract}
The bacterial composition of permafrost samples taken during drilling of frozen marine sediments in the area of the Barentsburg coal mine on the east coast of Grønfjord Bay of Western Spitsbergen has been studied. The study was based on the analysis of the V4 region of the 16S rRNA gene, carried out using next generation sequencing, as well as using classical microbiological methods (direct luminescence microscopy and aerobic cultivation).The total cell number in permafrost samples ranges from $6.73 \pm 0.73 \cdot 10^{6}$ to $3.37 \pm 0.19 \cdot 10^{7}$ cells per $\mathrm{g}$. The number of cultivable aerobic bacteria in frozen samples on 1/5 TSA and $\mathrm{R}_{2} \mathrm{~A}$ media ranges from 0 to $6.20 \pm 0.45 \cdot 10^{4} \mathrm{CFU} / \mathrm{g}$. Isolates of aerobic bacteria were identified by $16 \mathrm{~S}$ rRNA gene analysis as representatives of the genera Arthrobacter, Pseudarthrobacter, Psychrobacter, and Rhodoferax. The dominant phyla of the Bacteria domain were Actinobacteria, Proteobacteria, Chloroflexi, Nitrospirae and Firmicutes.
\end{abstract}


As a result of phylogenetic analysis of the dominant operational taxonomic units, representatives of methaneoxidizing, sulfate-reducing bacteria, as well as heterotrophic bacteria involved in the transformation of organic matter were found.

Keywords: Western Spitsbergen, permafrost, marine sediments, cultivable aerobic bacteria, V4 region of $16 \mathrm{~S}$ rRNA, Bacteria domain, methane.

About the authors

KARAEVSKAYA Ekaterina Sergeevna - State Scientific Centre of the Russian Federation «Arctic and Antarctic Research Institute». Russia, 199397, St. Petersburg, Bering st., 38; Vavilov Institute of General Genetics, Russian Academy of Sciences. Russia, 119991, Moscow, Gubkina st., 3. E-mail: katya_k_s@mail.ru

DEMIDOV Nikita Eduardovich - State Scientific Centre of the Russian Federation «Arctic and Antarctic Research Institute». Russia, 199397, St. Petersburg, Bering st., 38. E-mail: nikdemidov@mail.ru

KAZANTSEV Vladimir Sergeevich - Obukhov Institute of Atmospheric Physics, Russian Academy of Sciences. Russia, 119017, Moscow, Pyzhyovskiy alleyway, 3. E-mail: kazantsev@ifaran.ru

ELIZAROV Ivan Mikhailovich - Federal Research Centre «Fundamentals of Biotechnology» of the Russian Academy of Sciences, Vinogradsky Institute of Microbiology, Russian Academy of Sciences. Russia, 117312, Moscow, av. 60 Anniversary of October, 2-2. E-mail: ivan.elizarov@gmail.com

KHALOSHIN Alexander Grigorievich - Scientific-Analitical Centre, Aprelevka Branch of the All-Russian Research Geological Oil Institute. Russia, 143360, Moscow region, Aprelevka, 1st Ketritsa st., 1.

PETROV Alexander Leonidovich - Scientific-Analitical Centre, Aprelevka Branch of the All-Russian Research Geological Oil Institute. Russia, 143360, Moscow region, Aprelevka, 1st Ketritsa st., 1. E-mail: a.petrov@vnigni.ru

KARLOV Denis Sergeevich - All-Russian Research Institute for Agricultural Microbiology. Russia, 196608, St. Petersburg; Pushkin, Podbelskogo highway, 3. E-mail: deniskarlov23@gmail.com

SCHIRRMEISTER Lutz - Alfred Wegener Institute, Helmholtz Center for Polar and Marine Research, Department of Permafrost Research. Germany, 14473, Potsdam, Telegrafenberg A45. E-mail: lutz.schirrmeister@awi.de

BELOV Andrey Antonovich - Lomonosov Moscow State University, Faculty of Soil Science. Russia, 119991, Moscow, Leninskie Gory, 1. E-mail: and.ant.be@gmail.com

WETTERICH Sebastian - Alfred Wegener Institute, Helmholtz Center for Polar and Marine Research, Department of Permafrost Research. Germany, 14473, Potsdam, Telegrafenberg A45. E-mail: sebastian.wetterich@awi.de

Cite this article as: Karaevskaya E.S., Demidov N.E., Kazantsev V.S., Elizarov I.M., Khaloshin A.G., Petrov A.L., Karlov D.S., Schirrmeister L., Belov A.A., Wetterich S. Bacterial communities of frozen quaternary sediments of marine origin on the coast of Western Spitsbergen, Geofizicheskie Protsessy i Biosfera (Geophysical Processes and Biosphere), 2021, vol. 20, no. 2, pp. 75-98 (in Russian). https://doi.org/10.21455/gpb2021.2-5

English version: Izvestiya, Atmospheric and Oceanic Physics, 2021, vol. 57, iss. 8. ISSN: 0001-4338 (Print), 1555-628X (Online). https://link.springer.com/journal/volumesAndIssues/11485 